Wilfrid Laurier University

Scholars Commons @ Laurier

$10-2010$

\title{
Evolutionary History and Taxonomy of the Cuscuta umbellata complex (Convolvulaceae): Evidence of Extensive Hybridization from Discordant Nuclear and Plastid Phylogenies
}

\author{
Mihai Costea \\ Wilfrid Laurier University, mcostea@wlu.ca \\ Saša Stefanović \\ University of Toronto
}

Follow this and additional works at: https://scholars.wlu.ca/biol_faculty

Part of the Biology Commons

\section{Recommended Citation}

Costea, Mihai and Stefanović, Saša, "Evolutionary History and Taxonomy of the Cuscuta umbellata complex (Convolvulaceae): Evidence of Extensive Hybridization from Discordant Nuclear and Plastid Phylogenies" (2010). Biology Faculty Publications. 73.

https://scholars.wlu.ca/biol_faculty/73

This Article is brought to you for free and open access by the Biology at Scholars Commons @ Laurier. It has been accepted for inclusion in Biology Faculty Publications by an authorized administrator of Scholars Commons @ Laurier. For more information, please contact scholarscommons@wlu.ca. 


\title{
Evolutionary history and taxonomy of the Cuscuta umbellata complex (Convolvulaceae): Evidence of extensive hybridization from discordant nuclear and plastid phylogenies
}

\author{
Mihai Costea $^{1} \&$ Saša Stefanović $^{2}$ \\ 1 Department of Biology, Wilfrid Laurier University, Waterloo, Ontario N2L3C5, Canada \\ 2 Department of Biology, University of Toronto Mississauga, Mississauga, Ontario L5L 1C6, Canada \\ Author for correspondence: Mihai Costea, mcostea@wlu.ca
}

\begin{abstract}
The Cuscuta umbellata complex is one of the 15 major clades recently circumscribed in C. subg. Grammica. Most of its members occur in North America and the Caribbean (C. desmouliniana, C. lacerata, C. leptantha, C. liliputana, C. odontolepis, C. polyanthemos, C. tuberculata, C. umbellata), but three species (C. acuta, C. membranacea, C. umbellata) grow in South America, and one (C. hyalina) is found as a native species in India, Pakistan and Eastern to South Africa. Basic morphology, scanning electron microscopy and sequence data from the nuclear internal transcribed spacer (ITS) and the plastid trnL-F region were used to reconstruct the phylogeny, gain a better understanding of the evolutionary history, and determine species boundaries. Our results show that in its currently accepted delimitation C. umbellata is polyphyletic. Discordances between phylogenies derived from plastid and nuclear data strongly suggest that at least four independent hybridization events have occurred in the evolution of this species group, rendering relationships among its members more complex than previously thought. One of these reticulation events involves C. umbellata var. reflexa, a taxon that has been considered synonymous to C. umbellata var. umbellata in the last decades. This hybrid is morphologically intermediate but distinct from its putative parents, C. odontolepis or C. acuta on the maternal side, and C. umbellata (var. umbellata) on the paternal side, which supports its treatment as a new species, C. legitima. Cuscuta umbellata is further redefined to exclude C. umbellata var. dubia, which is merged into C. desmouliniana. A new classification is provided, together with an identification key, descriptions, illustrations, and geographical distributions for the twelve species of the clade.
\end{abstract}

Keywords Convolvulaceae; Cuscuta; hybridization; ITS; molecular phylogeny; morphology; taxonomy; trnL-F

\section{INTRODUCTION}

With more than 200 species and over 70 varieties Cuscuta L. (dodders) is one of the most diverse and challenging groups of parasitic plants. The genus is nearly cosmopolitan, but the highest diversity of species (ca. 140-160) is encountered in the Americas (Yuncker, 1932; García \& Martín, 2007; Stefanović \& al., 2007). Dodders are important both economically and ecologically. A few species are among the most damaging pests worldwide, being capable of producing considerable losses to agricultural crops (Parker \& Riches, 1993; Holm \& al., 1997; Costea \& Tardif, 2006). Surprisingly, however, numerous other species in this genus are presumed extinct or require conservation measures (Costea \& Stefanović, 2009a).

Almost eight decades after Truman G. Yuncker's monograph (Yuncker, 1932), systematics of Cuscuta is receiving a renewed interest. Two of the three accepted subgenera, $C$. subg. Cuscuta and subg. Grammica, have been recently the subject of broad-scale phylogenetic studies (García \& Martín, 2007; Stefanović \& al., 2007). In C. subg. Grammica, the largest and most complicated infrageneric group, 15 major lineages have been circumscribed (Stefanović \& al., 2007), with little correspondence to Yuncker's sections and subsections. In parallel, a series of focused systematic studies have been initiated to investigate these clades at species level. To date, a total of five major Grammica clades have been examined: four that comprise mostly species from the territory covered by Flora of North America (Costea \& al., 2006a-c; Costea \& Stefanović, 2009b; Costea \& al., 2009), and one with predominantly Mexican dodders (Costea \& al., 2008).

Our present study continues this series by investigating "clade L" (Stefanović \& al., 2007), referred to here as the "Cuscuta umbellata complex" in the absence of a formal section name (to be published with a new infrageneric classification of the genus; Costea \& al., in prep.). The core of this group is represented by species of the former $C$. subsect. Umbellatae in which Yuncker $(1932,1965)$ included nine species characterized by umbellate inflorescences and dehiscent capsules: C. umbellata, C. deltoidea, C. desmouliniana, C. fasciculata, C. gracillima, C. hyalina, C. lacerata, C. macvaughii, C. saccharata, and C. serruloba. However, recent molecular results (Stefanović \& al., 2007; Stefanović \& Costea, 2008) have shown that the composition of the clade is radically different. Five other species previously included by Yuncker (1932) in various sections and subsections of $C$. subg. Grammica are also part of the C. umbellata complex (Stefanović \& al., 2007; Stefanović \& Costea, 2008). Two of these, C. acuta and C. membranacea, have indehiscent capsules (previously included in C. sect. Eugrammica subsect. Acutae; Yuncker, 1932; Hunziker, 1949), while the rest have circumscissile capsules: $C$. odontolepis (formerly in C. sect. Eugrammica subsect. Odontolepisae; Yuncker 1932), C. tuberculata, C. leptantha, and C. polyanthemos (formerly 
in C. sect. Eugrammica subsect. Leptanthae; Yuncker, 1932). In addition, $C$. lilliputana, a new species that is nested within this group, has been recently described (Stefanović \& Costea, 2008). In contrast, C. gracillima, C. sidarum (= C. saccharata), C. deltoidea (=C. serruloba) do not belong to the C. umbellata clade as previously thought by Yuncker $(1932,1965)$, but form a separate group (Stefanović \& al., 2007; Costea \& al., 2008).

Most of the members of the $C$. umbellata complex are known to occur in southwestern U.S.A. and Mexico, but three species (C. umbellata, C. acuta, C. membranacea) grow in South America, and another one $(C$. hyalina) can be found in India, Pakistan and Africa. Recent phylogenetic studies have clearly indicated that the boundaries of some species (e.g., C. umbellata and C. desmouliniana) must be reconsidered (Stefanović \& al., 2007; Stefanović \& Costea, 2008). These studies have also revealed discordant nuclear and plastid phylogenies which suggested that at least two of the species, $C$. liliputana and $C$. desmouliniana, likely have a hybrid origin (Stefanović \& Costea, 2008). These cases of reticulation, together with the disjunct distribution of the taxa, have shown that the evolutionary history of the C. umbellata clade is much more complex than previously thought. In view of these interesting preliminary findings based on relatively limited sampling within the C. umbellata complex, we have studied numerous herbarium specimens that have accumulated worldwide since Yuncker's monographs (Yuncker, 1932, 1965). The aims of this study are to (1) recover the evolutionary history of the C. umbellata complex based on nuclear ITS and plastid $\operatorname{trn} L-F$ sequences and further investigate the extent of reticulate evolution known to occur in this group; (2) investigate the morphology and micromorphology of the taxa involved; and (3) provide a new classification of the C. umbellata complex with the description of a new species, C. legitima.

\section{MATERIALS AND METHODS}

Taxon sampling. - We have studied specimens from over 100 herbaria in connection with the upcoming treatments of Cuscuta for Flora of North America Project, Flora Neotropica, and a future monograph of the genus. A subset of 34 accessions, representing eleven ingroup species of the C. umbellata complex, was used for the molecular phylogenetic analyses (Appendix 1). Efforts were made to sample multiple accessions, particularly for those species spanning large biogeographical ranges (e.g., C. hyalina) and/or those with variable morphology (e.g., C. umbellata). As a result, two to nine individuals are included in the molecular analyses for all but one rare species, $C$. membranacea, known only from its type locality. In addition, several taxa (C. lacerata, C. fasciculata, C. hyalina var. nubiana, C. umbellata var. dubia) are known only from their type specimens (Yuncker, 1921, 1932), and C. umbellata var. desertorum from two historical collections (Engelmann, 1859; Yuncker, 1932). Hence, these taxa could not be sampled for the molecular analyses. Based on our previous, more inclusive phylogenetic analyses of Cuscuta subg. Grammica (Stefanović \& al., 2007; Stefanović \& Costea, 2008), we selected two species from the $C$. gracillima clade as outgroup (Appendix 1).

Morphology and micromorphology. - Descriptions are based on herbarium material (Appendix 2). We examined the basic morphology of rehydrated flowers and capsules under a Nikon SMZ1500 stereomicroscope equipped with a PaxCam Arc digital camera and Pax-it 7.0 software (MIS Inc., Villa Park, Illinois, U.S.A.). Micromorphological measurements and pictures were taken at $10 \mathrm{kV}$ using a Hitachi SU1510 scanning electron microscope. Herbarium samples (Appendix 2) were coated with $30 \mathrm{~nm}$ gold using an Emitech K 550 sputter coater. The terminology regarding the micromorphology of flowers, seeds capsules, and pollen follows Costea \& al. (2006a). Hundreds of photographs that illustrate details of the floral parts, pollen and fruit morphology for all the species (including the types) are available on the Digital Atlas of Cuscuta (Costea, 2007-onwards). The geographical distribution of taxa, phenology, elevation and host ranges are based on observation made from herbarium specimens.

Molecular techniques and alignments. - To infer phylogenetic relationships among species of the C. umbellata complex, sequences for the internal transcribed spacer (ITS) region of nuclear ribosomal DNA (nrDNA) as well as $\operatorname{trnL}-F$ intron/spacer region from the plastid genome (ptDNA) were obtained. In addition to the DNA samples used in previous studies (Stefanović \& al., 2007; Stefanović \& Costea, 2008), total genomic DNA was isolated from newly obtained specimens as well. DNA extractions, polymerase chain reaction (PCR) reagents and conditions, amplicon purifications, cloning, as well as sequencing procedures followed the protocols detailed in Stefanović \& al. (2007). Initial sequencing of nuclear and plastid amplicons was done directly. However, in the cases where significant polymorphism was detected, the PCR product was cloned and multiple clones per individual were sequenced. Sequences generated in this study are deposited in GenBank (accession numbers HM748863-HM748905; see Appendix 1). Sequences were aligned manually using Se-Al v.2.0a11 (Rambaut, 2002).

Phylogenetic analyses. - Phylogenetic analyses were conducted under parsimony and Bayesian optimality criteria; summary descriptions of these analyses, for individual as well as combined datasets, are provided in Table 1.

Under the parsimony criterion, nucleotide characters were treated as unordered and all changes were equally weighted. Depending on the number of operational taxonomic units (OTUs) included, different search strategies were employed for the different matrices, using PAUP* v.4.0b10 (Swofford, 2002). For the ITS matrix, searches for most parsimonious (MP) trees were performed using a two-stage strategy. First, the analyses involved 10,000 replicates with stepwise random taxon addition, tree bisection-reconnection (TBR) branch swapping saving no more than 10 trees per replicate, and MULTREES off. The second round of analyses was performed on all trees in memory with the same settings except with MULTREES on. Both stages were conducted to completion or until one million trees were found. For the $\operatorname{trn} L-F$ matrix, a full heuristic search was performed, involving 1000 replicates with stepwise 
random taxon addition, TBR branch swapping, and MULTREES option on. Given the relatively moderate number of terminal units included in the combined dataset, we performed a Branch-and-Bound search, therefore ensuring recovery of all MP trees. In all three cases, support for clades was inferred by nonparametric bootstrapping (Felsenstein, 1985), using 500 heuristic bootstrap replicates, each with 20 random addition cycles, TBR branch swapping, and MULTREES option off (DeBry \& Olmstead, 2000). Nodes receiving bootstrap (BS) values $<60 \%, 60 \%-75 \%$, and $>75 \%$ were considered weakly, moderately, and strongly supported, respectively.

Bayesian phylogenetic inferences were performed using MrBayes v.3.1.2 (Ronquist \& Huelsenbeck, 2003). ModelTest v.3.7 (Posada \& Crandall, 1998) was used to determine the model of sequence evolution that best fit the data by the Akaike Information Criterion (AIC), starting with the parsimony-derived tree rather than the neighbor-joining default. The Tamura-Nei (TrN) model of DNA substitution (Tamura \& Nei, 1993), with rate variation among nucleotides following a discrete gamma distribution $(\operatorname{Tr} N+G)$, was selected as the bestfit for the ITS sets. For the trnL-F matrix, the F81 (Felsenstein, 1981) model was selected. Each Bayesian analysis consisted initially of two runs of one million generations from a random starting tree using the default priors and four Markov chains sampled every 100 generations. If needed, the run lengths were increased until the standard deviation of split frequencies between two runs was well below 0.01 (see Table 1 for details on MrBayes settings and number of generations used for each of three analyses). Convergence of the chains was determined by examining the plot of all parameter values and the $-\ln L$ against generation using Tracer v.1.3 (Rambaut \& Drummond, 2004). Stationarity was assumed when all parameter values and $-\ln L$ had stabilized. Burn-in trees were discarded and the remaining trees and their associated parameters were saved. Because no significant differences between two runs were detected (for each of the three separate Bayesian analyses; Table 1), the reported topologies and posterior probabilities (PP) are based on trees from pooled runs. Only the nodes receiving $\geq 0.95 \mathrm{PP}$ were considered statistically significantly supported (Rannala \& Yang, 1996).

Topological incongruence and alternative hypothesis testing. - Conflict between datasets was first evaluated by visual inspection, by searching for the presence of conflicting and strongly supported topologies from individual matrices. For all the cases where such conflicts were found, reciprocally constrained topologies were constructed using MacClade v.4.06 (Maddison \& Maddison, 2003) and their cost in parsimony was assessed using PAUP* (Swofford, 2002). In

Table 1. Summary descriptions for sequences included in, phylogenetic analyses conducted on, and trees derived from, individual and combined datasets of the Cuscuta umbellata complex.

\begin{tabular}{|c|c|c|c|}
\hline & ITS (nuclear) & trnL-F (plastid) & Combined \\
\hline Number of OTUs included & 69 & 37 & 25 \\
\hline \multicolumn{4}{|l|}{ Sequence characteristics: } \\
\hline Aligned length & 643 & 543 & 1207 \\
\hline Variable sites & 253 & 45 & 191 \\
\hline Parsimony informative sites & 140 & 40 & 158 \\
\hline Mean AT content $(\%)$ & 47 & 64 & 54 \\
\hline \multicolumn{4}{|l|}{ Parsimony search conditions: } \\
\hline Algorithm & Two-stage heuristic & Full heuristic & Branch-and-Bound \\
\hline RSA/branch swapping/MULTREES & $\begin{array}{l}\text { 10,000/TBR/off; } \\
\text { Memory/TBR/on }\end{array}$ & 1000/TBR/on & $\mathrm{na} / \mathrm{na} / \mathrm{on}$ \\
\hline \multicolumn{4}{|l|}{ MP tree characteristics: } \\
\hline Number of trees & $>1,000,000$ & 1454 & 2100 \\
\hline Length & 376 & 48 & 251 \\
\hline $\mathrm{CI} / \mathrm{RI}$ & $0.795 / 0.947$ & $0.979 / 0.996$ & $0.873 / 0.956$ \\
\hline \multicolumn{4}{|l|}{ Bayesian search conditions: } \\
\hline Model of DNA evolution (MrBayes settings used) & $\begin{array}{l}\operatorname{TrN}+\mathrm{G} \\
(\mathrm{nst}=6 ; \text { rates }=\text { gamma })\end{array}$ & $\begin{array}{l}\text { F81 } \\
(\mathrm{nst}=2 ; \text { rates }=\text { equal })\end{array}$ & $\begin{array}{l}\text { Combined } \\
\text { (partitioned) }\end{array}$ \\
\hline Number of generations (number of runs) & $4 \times 10^{6}(2)$ & $1 \times 10^{6}(2)$ & $2 \times 10^{6}(2)$ \\
\hline Burn-in (\%) & 20 & 20 & 20 \\
\hline \multicolumn{4}{|l|}{ Bayesian tree characteristics: } \\
\hline Mean $-\ln L$ & -3509.959 & -1116.633 & -3115.534 \\
\hline Number of trees retained & 64,000 & 16,000 & 32,000 \\
\hline
\end{tabular}

$\mathrm{CI}$, consistency index (excluding parsimony uninformative characters); df, degrees of freedom; nst, number of substitution states; OTU, operational taxonomic unit; RI, retention index; RSA, random sequence addition; TBR, tree bisection and reconnection. 
this fashion, for each case of the strongly supported incongruence between the two datasets, one randomly chosen MP tree representing topological results obtained from nuclear data was imposed on plastid data and vice versa. To evaluate the significance among these alternative phylogenetic hypotheses, we implemented the one-tailed Shimodaira-Hasegawa tests (SH tests; Shimodaira \& Hasegawa, 1999; Goldman \& al., 2000) in PAUP*. The test distributions were obtained using the reestimated log likelihoods (RELL; Kishino \& Hasegawa, 1989) with 10,000 bootstrap replicates.

\section{口 RESULTS}

General morphology and micromorphology. - Although the clade of $C$. umbellata is relatively easy to distinguish from other major groups of Cuscuta (see Stefanović \& al., 2007), most of its species are notoriously difficult to separate from each other. The overall morphology of this clade reflects its phylogenetic affinities with the $C$. gracillima clade ("clade N" in Stefanović \& al., 2007). The loose, umbellate inflorescence encountered in most species, the shape of the calyx lobes as well as the morphology of the capsules are relatively similar to the species of the C. gracillima complex (Costea \& al., 2008). However, unlike in the latter group, the stems of species in the $C$. umbellata clade are persistent at maturity and inflorescences do not emerge directly from the host's stems (Costea $\&$ al., 2008).

Papillae are present on the perianth of some species, both on the calyx and corolla (C. liliputana, C. leptantha, $C$. desmouliniana; Fig. 1D, G, I), or only on the corolla (C. odontolepis, C. tuberculata, C. umbellata; Fig. 1A, E). Cuscuta desmouliniana, C. tuberculata and sometimes C. liliputana are the members of this clade that have multicellular protuberances with stomata on the bracts and calyx lobes (Fig. 1G-H). Similar structures with an unknown role have been also reported from C. draconella in the C. californica clade (Costea \& Stefanović, 2009b). Infrastaminal scales with laticifers in the fimbriae are present in most species (Fig. 1B-C), except for $C$. hyalina in which scales are reduced or absent. The pollen is relatively uniform among species, comparable to that of $C$. indecora and C. gracillima clades (Costea \& al., 2006b, 2008). Pollen grains are 3(-4)-zonocolpate, subspheroidal to prolate with perforate or imperforate tectum (for images see Costea, 2007 onwards; for descriptions see Welsh \& al., 2010). In most species, capsules dehisce by a circular line at the base of the fruit. The capsules of the Caribbean form of C. umbellata var. umbellata dehisce late by a more or less irregular line (also found at the base of the fruit). The fruit is indehiscent in C. acuta and C. membranacea, although the capsule may tear irregularly at the base if pressure is applied. The seeds are angled; the seed coat cells are alveolate when dry and papillose when hydrated, 20-55 $\mu \mathrm{m}$ in diameter. The hilum region is terminal and round, and the vascular scar of the funiculum is short, vertical.

Sequences and alignments. - Summary descriptions for sequences obtained from ITS and $\operatorname{trn} L-F$ regions are presented in Table 1. Sequences newly generated for this study were incorporated together with the relevant portions of the alignments used in our previous analyses (Stefanović \& al., 2007; Stefanović \& Costea, 2008). Although these two noncoding regions exhibited length variation, the alignments among the ingroup taxa were straightforward throughout the entire length of these matrices and were used in their entirety for phylogenetic analyses. This is in contrast to the higher-level phylogenetic study of Cuscuta subg. Grammica (Stefanović \& al., 2007; Stefanović \& Costea, 2008) in which large portions of $\operatorname{trn} L-F$ could not be aligned across major clades, and these consequently had to be excluded from the analyses. Despite repeated attempts (including efforts to amplify the fragments in two parts), sequence data could not be obtained for one or the other region from a few individuals, presumably due to the poor quality or limited quantity of the DNA extracted from some older herbarium specimens.

Unconstrained analyses and overall levels of support. - Preliminary phylogenetic analyses were conducted on individual matrices with the inclusion of the outgroup taxa (trees not shown). Those analyses indicated that the first split within the $C$. umbellata group occurs between the C. leptantha/C. polyanthemos clade on one side, and the remainder of this complex on the other, in agreement with our previous broad-scale results ("clade L" in Stefanović \& al., 2007; Stefanović \& Costea, 2008). Taking this into account, in all subsequent analyses we used C. leptantha and $C$. polyanthemos as functional outgroup (Figs. 2-4), allowing for the full usage of all available nuclear and plastid data. Summary descriptions of trees derived from individual and combined datasets are presented in Table 1. For all these three analyses, the strict consensuses of equally parsimonious trees (not shown) resulted in relationships that were topologically identical or nearly identical to the respective results derived under the Bayesian criterion (Figs. 2-3).

Four major clades labeled A-D were resolved within the Cuscuta umbellata complex with nuclear ITS sequences (Fig. 2, left). All of these clades have branches with substantial length subtending them and have received strong bootstrap support $(97 \%-100 \%)$ as well as significant posterior probabilities $(\geq 0.95)$. Clade A groups all the accessions/clones of C. umbellata, C. hyalina, C. membranacea, C. liliputana, and C. desmouliniana. In addition, this lineage contains some but not all the clones derived from the $C$. legitima accessions. In contrast to the strong support for this clade, the relationships within it remained mostly unresolved and unsupported, with a couple of exceptions. Namely, all the members of $C$. hyalina are found grouped together and sister to the sole representative of C. membranacea. Both of these results received strong support ( $98 \%$ BS; $\geq 0.95$ PP). Clade B consists of all the representatives of C. acuta and C. odontolepis plus the remainder of the clones obtained from $C$. legitima accessions. Similarly to the situation described above for clade $\mathrm{A}$, the relationships within clade $\mathrm{B}$ are mainly unresolved as well. Moderate support was observed only for a clade grouping all the $C$. acuta clones $(52 \% \mathrm{BS} ; \geq 0.95$ PP), while the representatives of the other two species are found interspersed among each other. Clade $\mathrm{C}$ contains exclusively C. tuberculata individuals, and clade D groups together two 


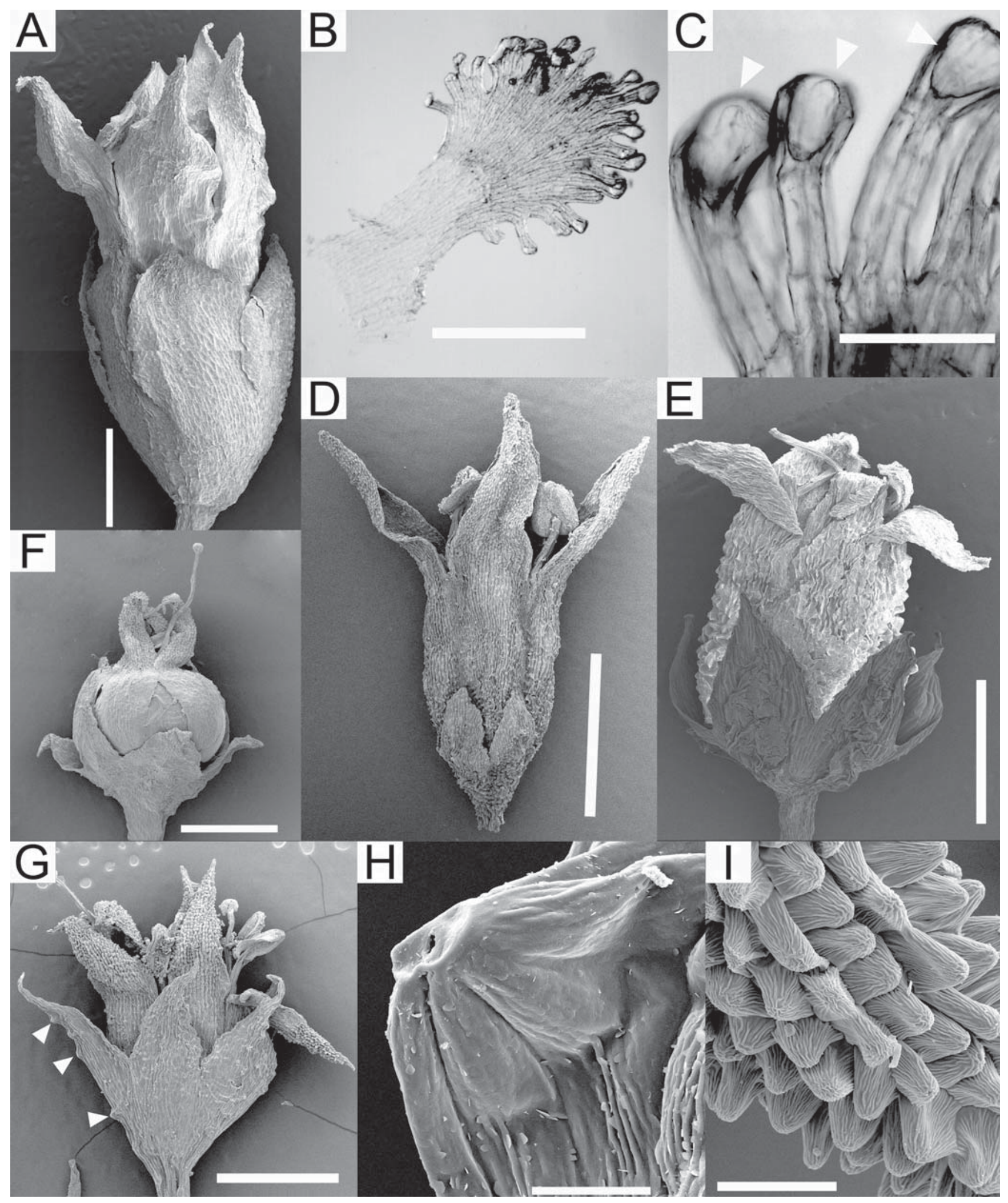

Fig. 1. Morphological and micromorphological features of species from the Cuscuta umbellata complex. A, Cuscuta odontolepis flower; B, infrastaminal scale of C. umbellata (var. umbellata); C, laticifers (arrowheads) in the infrastaminal scales of C. umbellata (var. umbellata); D, C. leptantha flower; $\mathbf{E}, C$. tuberculata flower; $\mathbf{F}$, capsule and persistent corolla in $C$. desmouliniana; $\mathbf{G}$, flower of $C$. desmouliniana with multicellular protuberances on the calyx (arrowheads); $\mathbf{H}$, multicellular protuberance with stomata; I, papillae on the corolla of $C$. desmouliniana. Bars: A, D-G, $1 \mathrm{~mm} ; \mathrm{B}, 0.5 \mathrm{~mm} ; \mathrm{C}, 100 \mu \mathrm{m} ; \mathrm{H}, 30 \mu \mathrm{m} ; \mathrm{I}, 60 \mu \mathrm{m}$. 


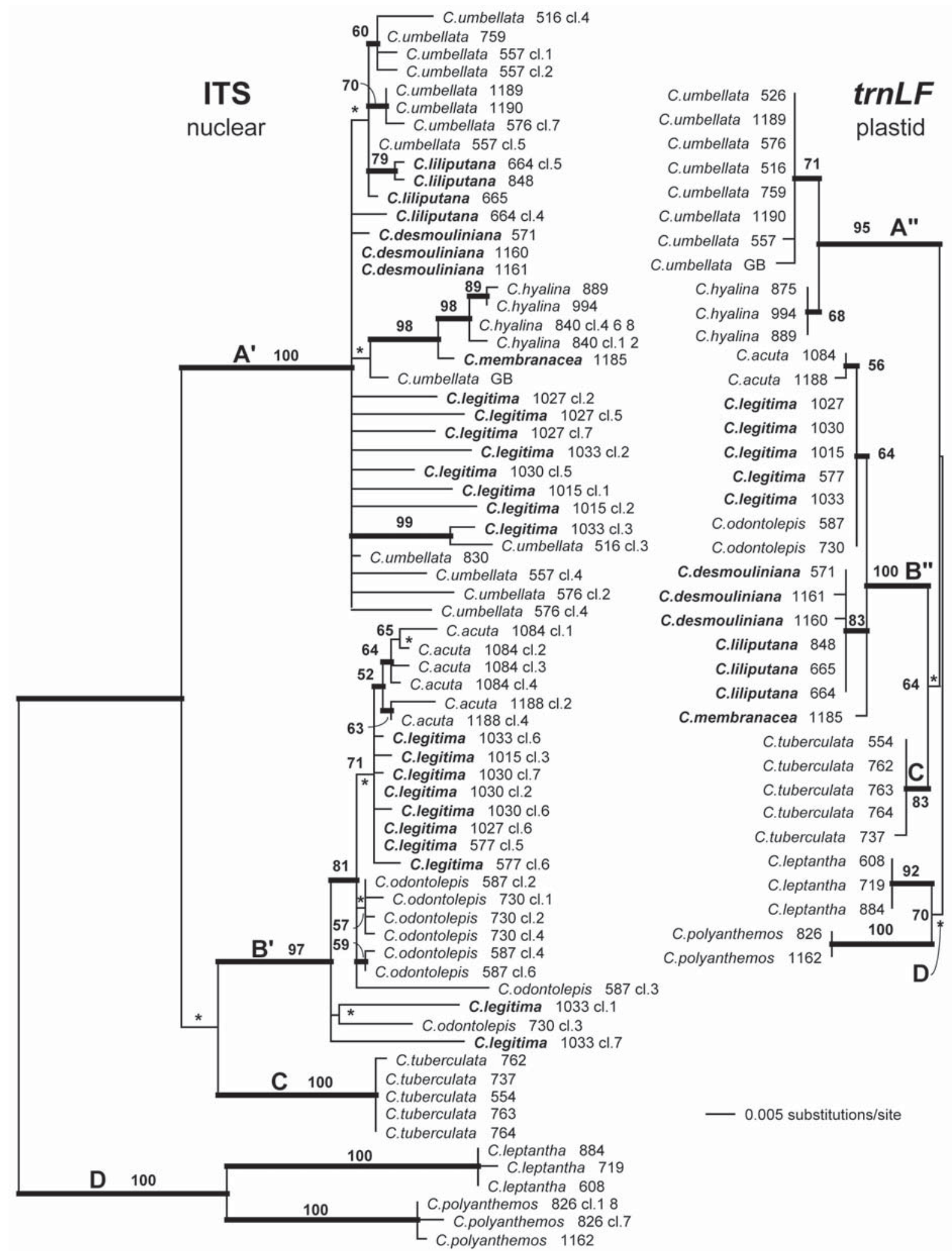

Fig. 2. Phylogenetic relationships among species of the Cuscuta umbellata complex derived from separate Bayesian analyses of nuclear and plastid sequences. Majority-rule consensus trees with mean branch lengths are drawn at the same scale for both phylograms. Four major lineages are labeled A-D. Prime and double-prime symbols indicate clades exhibiting substantial topological incongruence between nuclear and plastid results. Species with conflicting positions are depicted in bold. Parsimony bootstrap values are indicated for nodes supported $\geq 50 \%$. Asterisks indicate branches with Bayesian posterior probability $<0.95$; all other branches have posterior probability $\geq 0.95$ (thick lines). Numbers following species names correspond to DNA accessions (see Appendix 1); in addition, for the ITS data different clones are labeled, if applicable. 
remaining species from this complex, C. leptantha and C. polyanthemos; all these results received maximum support $(100 \%$ $\mathrm{BS} ; \geq 0.95 \mathrm{PP}$ ).

Analyses of plastid $\operatorname{trn} L-F$ matrix also recovered four major, well-defined, and well-supported lineages (A-D; Fig. 2, right). However, the composition of two of those lineages, clades $\mathrm{A}$ and $\mathrm{B}$, differs substantially compared to that obtained from the nuclear matrix. With plastid data, clade A contains only individuals of C. umbellata and C. hyalina. Members of these two species are reciprocally monophyletic and both are moderately supported ( $71 \%$ and $68 \%$ BS, respectively; $\geq 0.95$ PP for both clades). Similarly to the ITS results, clade B contains C. acuta and $C$. odontolepis. However, in addition to these two species, and unlike in the results obtained with nuclear data, all the individuals of C. membranacea, C. liliputana, C. desmouliniana, and C. legitima are also confined to clade B, with strong support $(100 \% \mathrm{BS} ; \geq 0.95 \mathrm{PP})$. Relationships within clade B are only weakly supported with the exception of the C. liliputanal desmouliniana subclade ( $83 \% \mathrm{BS} ; \geq 0.95 \mathrm{PP})$. The remaining two major groups, clades $\mathrm{C}$ and $\mathrm{D}$, are identical in composition between the nuclear and plastid matrices, and consist of C. tuberculata and C. leptantha/polyanthemos individuals, respectively.

The combined analyses were conducted on a dataset in which nuclear and plastid sequences were concatenated but the accessions with strongly supported conflicting positions

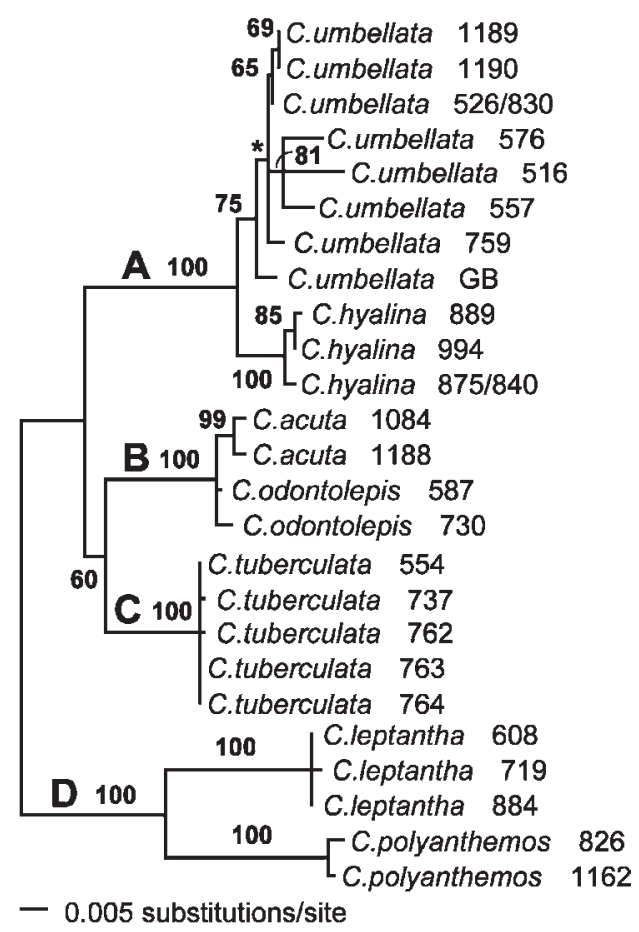

Fig. 3. Majority-rule consensus tree with mean branch lengths from the Bayesian analysis of combined nuclear (ITS) and plastid ( $\operatorname{trn} L-F$ ) data showing the backbone relationships among species of the Cuscuta umbellata complex. Four major lineages are labeled A-D. Bootstrap values are indicated for nodes supported $\geq 50 \%$. The asterisk indicates a branch with posterior probability $<0.95$; all other branches have posterior probability $\geq 0.95$. Numbers following species names correspond to DNA accessions (see Appendix 1). in individual analyses excluded. Not surprisingly, the same basic underlying tree structure containing four major clades was recovered (Fig. 3). In addition, the combined data provided some support for the backbone relationships among these four lineages. Clades $\mathrm{B}$ and $\mathrm{C}$ were found sister to each other with stronger support $(60 \% \mathrm{BS} ; \geq 0.95 \mathrm{PP})$ than in individual analyses. Together, these two clades are sister to clade A. As previously indicated, the preliminary analyses including the outgroup placed C. leptantha and C. polyanthemos (i.e., clade D) as sisters to the rest of the C. umbellata complex, with strong support (100\% BS; $\geq 0.95 \mathrm{PP}$; trees not shown).

Tests of alternative tree topologies. - The analyses of separate nuclear and plastid matrices produced trees of remarkably similar topologies, with the exception of four striking and strongly supported conflicts (Figs. 2 and 4) whose topological discordances span across two major clades, A and B. According to the nuclear data, C.membranacea, C. liliputana, C. desmouliniana as well as a number of clones from $C$. legitima accessions belong to the strongly supported clade A. In contrast, the plastid haplotypes place all these four species within clade B. Using nuclear data yet enforcing $\operatorname{trn} L-F$ results on these species and constraining them individually or in combination to clade B, with $C$. acuta and C. odontolepis, produced trees 17-22 steps longer than the optimal trees. All these length differences were deemed strongly significant and were rejected based on the SH tests (Table 2). Similarly, constraining these species to group in a clade with $C$. umbellata and $C$. hyalina (following the ITS results) with plastid data yielded trees 5-6 steps longer. Despite the relatively small length penalty, these results were also rejected as significantly worse solutions by the SH tests (Table 2).

\section{DISCUSSION}

Evidence for hybridization in the Cuscuta umbellata complex and alternative explanations for the observed plastid-nuclear discordance. - Instances of reticulate evolution in plants can be detected through detailed analyses of discordance among different unlinked gene trees (Rieseberg, 1995; Sang \& Zhong, 2000). When the ptDNA tree is compared with an independently derived phylogenetic tree (from morphology or other molecular data), conflicting position of a taxon between phylogenies may be taken as evidence for the hybrid origin of this taxon (Sang \& Zhong, 2000; an illustration of this principle is depicted in Fig. 4). We present here evidence for four cases of strongly supported yet conflicting phylogenetic signals between ITS and trnL-F sequence data for four species of the Cuscuta umbellata complex. Two of these cases, $C$. desmouliniana and C. liliputana, were already described and discussed in detail in our previous broad-scale assessment of hybridization in Cuscuta subg. Grammica (Stefanović \& Costea, 2008). The other two putative cases of hybridization involving C. membranacea and C. legitima are documented here for the first time.

In addition to hybridization, strongly conflicting gene trees can result from several other biological phenomena (e.g., Maddison, 1997; Wendel \& Doyle, 1998), as discussed in detail for the Cuscuta cases by Stefanović \& Costea (2008). While 

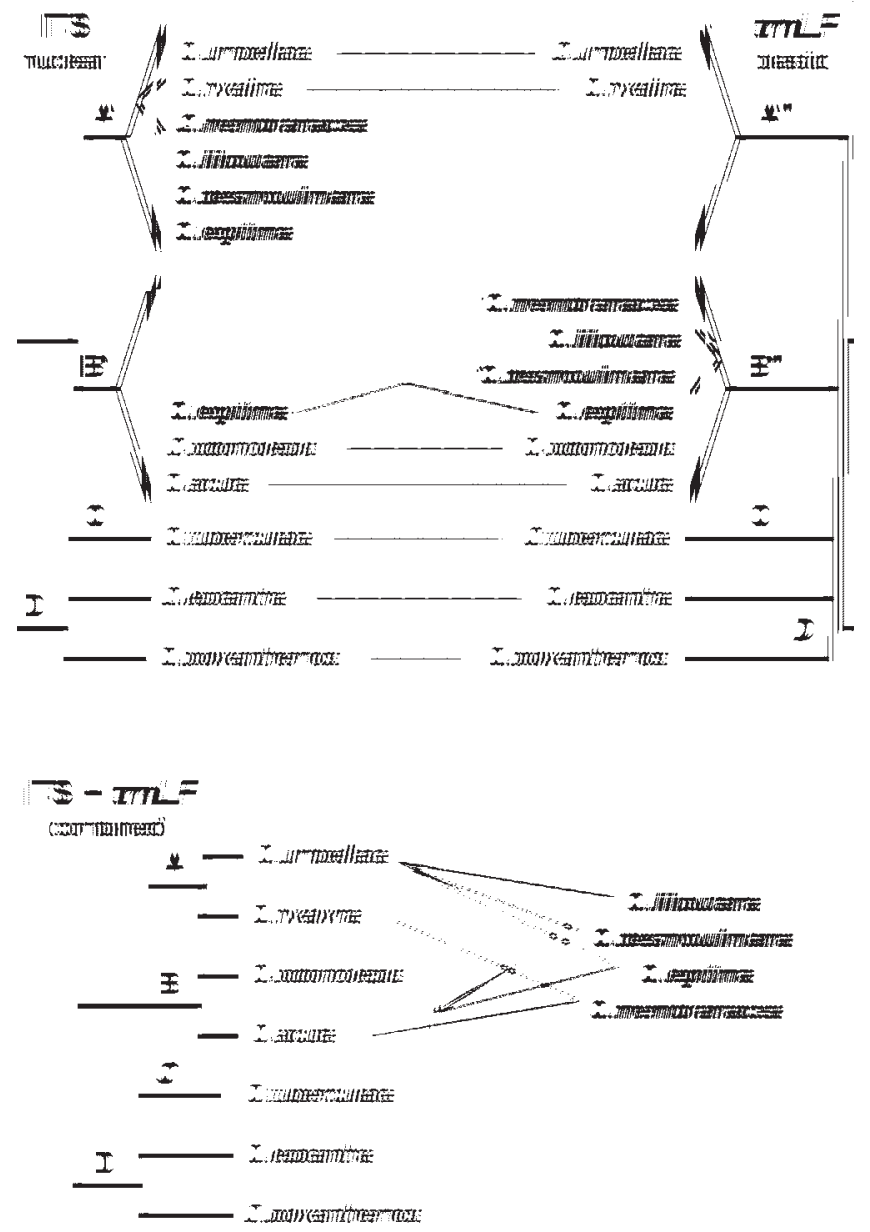

Fig. 4. Schematic overview of phylogenetic relationships within the Cuscuta umbellata complex deduced from separate and combined analyses of nuclear and plastid sequences. Four major lineages are labeled A-D. For simplicity, only the strongly supported backbone nodes are shown as resolved. Solid lines illustrate the conflicting topologies between nuclear and plastid data indicative of hybrid origin of involved species (in bold). Dashed lines connect species whose topology is congruent between the two datasets. The combined topology depicts inferred parental species of putative hybrid taxa. a disproportionately large number of the reported horizontal gene transfer (HGT) events involve parasitic plants (Davis \& Wurdack, 2004; Mower \& al., 2004; Nickrent \& al., 2004; Davis \& al., 2005), the discordances discussed here are at lower phylogenetic levels, where hybridization is expected to occur, and they involve nrDNA and ptDNA, for which there are virtually no known cases of HGT in land plants despite extensive amounts of available data (Rice \& Palmer, 2006).

Paralogy (i.e., gene duplication followed by differential deletion) is also not likely to be the cause for the topological discrepancy between plastid and nuclear phylogenies detected in our study. Although nrDNA is present in multiple copies in plants, it generally evolves in unison through the process of concerted evolution (Zimmer \& al., 1980; Buckler \& al., 1997). However, despite our intensive cloning efforts, ITS sequences from putative hybrids either were not different within a given species or showed only limited amount of polymorphism. When present, the paralogous sequences were most closely related to each other, consistent with either relatively recent duplication events or minor DNA polymerase errors rather than with the divergent ancestral paralogs (Stefanović \& al., 2007; Stefanović $\&$ Costea, 2008). The only significant departure from this was found in the C. legitima case. In this species, almost all accessions yielded two substantially distinct sets of clones, phylogenetically segregated into two clades (A and B in Figs. 2 and 4). The presence of two ribotypes is interpreted here as an additional evidence for the hybrid origin of this species. The additive pattern observed in nrDNA arrays of $C$. legitima is likely due to a recent hybridization event following which concerted evolution did not have time to homogenize towards one of the parental types (e.g., Sang \& al., 1995 in Paeonia; Ainouche \& Bayer, 1997 in Bromus; reviewed by Álvarez \& Wendel, 2003). On the other side, the trnL-F sequences used here are located in the large single-copy region of Cuscuta plastids (Funk \& al., 2007; McNeal \& al., 2007) and hence are likely to be orthologous. No polymorphism for this ptDNA region was observed within any individual and very little, if any, polymorphism was seen among different individuals from the same species.

Lineage sorting represents potentially the strongest alternative explanation but for the cases presented here we still

Table 2. Results of the Shimodaira-Hasegawa (SH) tests for comparison between highly supported yet incongruent topologies recovered from nuclear and plastid datasets of the Cuscuta umbelata species complex. Probabilities below 0.05 (i.e., tree topology rejected as significantly worse) are indicated in bold.

\begin{tabular}{|c|c|c|c|c|}
\hline Dataset & Constrained topology & Length & $\begin{array}{l}\text { Length } \\
\text { difference }\end{array}$ & SH test \\
\hline \multirow[t]{4}{*}{ Nuclear (ITS) } & Optimal tree (Figs. 2, 4; left) & 376 & Best & 1.000 \\
\hline & C. membranacea constrained to clade B & 394 & 18 & 0.001 \\
\hline & C. legitima constrained to clade B & 398 & 22 & $<0.001$ \\
\hline & C. liliputana and C. desmouliniana constrained to clade B & 393 & 17 & 0.006 \\
\hline \multirow[t]{4}{*}{ Plastid $(\operatorname{trn} L-F)$} & Optimal tree (Figs. 2, 4; right) & 48 & Best & 1.000 \\
\hline & C. membranacea constrained to clade $\mathrm{A}$ & 53 & 5 & 0.025 \\
\hline & C. legitima constrained to clade $\mathrm{A}$ & 54 & 6 & 0.014 \\
\hline & C. liliputana and C. desmouliniana constrained to clade A & 53 & 5 & 0.025 \\
\hline
\end{tabular}


favor hybridization for a number of reasons. First, because the plastid genome is uniparentally inherited and haploid, the plastid haplotype tree has a substantially higher probability of shorter coalescence time, leading to the relatively rapid elimination of any polymorphism (Moore, 1995). Second, like the majority of Cuscuta species (Yuncker, 1932), the four species of putative hybrid origin included in our study have relatively narrow geographic distributions. Of these, C. membranacea is the only species represented by a single individual because it is known only from its type locality. By contrast, each of the other three putative hybrids are represented by multiple individuals (3-5), spanning their respective distribution ranges. Yet, in all cases, the results were identical (or nearly so) among all the individuals included. Third, perhaps as a result of the multiple hybridization events, hybrids and their putative parental species are so closely allied that their morphological intermediacy is readily apparent (see below for details).

Phylogenetic analyses of additional, independently inherited sequence data, such as low-copy nuclear genes, as well as critically needed cytological information (the chromosome number is known only from C. hyalina-Vij \& al., 1974) will help to further support the extent and importance of hybridization in the evolution of Cuscuta. However, in light of currently available molecular phylogenetic evidence for hybrid origins we discuss below the delineation of species within this complex.

Basis for species delimitation. - Due to the taxonomic difficulty of this clade, neither morphological nor molecular data alone allowed a corroboration of taxon boundaries. In some instances we had to make a decision based on one type of data alone. For example, in the cases where taxa were known from historical collections only (e.g., C. lacerata, C. fasciculata, C. umbellata var. desertorum), and DNA could not be extracted, a conclusion had to be reached solely based on morphology. In contrast, the evolutionary relationships and putative cases of hybridization inferred from molecular data lead us to maintain some species in the absence of a clear morphological distinctiveness. This is exemplified by the case of C. membranacea and C. acuta, two species from South America that are not only very similar morphologically to one another, but also difficult to separate from the morphotype of $C$. umbellata var. umbellata that grows on the Cape Verde islands, the Caribbean Islands and the N to NE coast of South America (see below).

Redefinition of Cuscuta umbellata and C. desmouliniana. - The delimitation of C. umbellata represents the prerequisite for the taxonomy of the entire clade. Kunth's protologue (Bonpland \& al., 1818), and later Choisy (1841) referred to a plant collected from central Mexico by Humboldt and Bonpland. Subsequently, Engelmann (1859) expanded C. umbellata to include other forms "from many localities along the United States and Mexican boundary line from northern Mexico, and from the Antilles". He also included here as a variety (' $\beta$ ?') C. desertorum, described on a herbarium specimen by Martius from Brazil, expanding therefore the geographical distribution of C. umbellata to South America (Engelmann, 1859). Yuncker (1921) increased even more the complexity of $C$. umbellata by adding two more varieties: $C$. umbellata var. reflexa from southern U.S.A. and northern Mexico and C. umbellata var. dubia from Sonora. In this study, we show that C. umbellata circumscribed with four varieties is polyphyletic and that only Engelmann's delimitation (1859) reflects the reconstructed phylogenetic relationships among taxa.

Cuscuta umbellata var. reflexa was described as a variety of C. californica from Texas by Coulter (1890) and was later transferred to C. umbellata by Yuncker (1921), who maintained this combination until 1965 when he reconsidered and merged it with the type variety (Yuncker, 1965). Consequently, subsequent North American overviews (e.g., Kartesz, 1999; USDANRCS, 2010) did not differentiate between the two entities, and C. umbellata var. reflexa has been generally considered synonymous to the type variety. However, our results have determined that $C$. umbellata var. umbellata and var. reflexa segregate in different clades of the complex and have different evolutionary histories (Figs. 2 and 4). In addition, C. umbellata var. reflexa differs from var. umbellata in larger flowers with acuminate calyx and corolla lobes (Fig. 5). Based on its molecular and morphologic distinction, C. umbellata var. reflexa is redefined as a species, and since the binomial $C$. reflexa is not available (C. reflexa Roxb., Pl. Coromandel 2: 3, pl. 104. 1798), we prefer to describe it as a new species, C. legitima (Fig. 5A-D).

Cuscuta umbellata var. dubia was described by Yuncker (1921, 1932, 1965) from a single, poor specimen collected in Sonora and is characterized by a calyx with revolute lobe bases and more or less angled sinuses. Revolute bases of calyx lobes can also be observed in typical $C$. desmouliniana, but the angled feature is not as conspicuous because the calyx lobes are usually narrower. Molecular data together with other morphological features (e.g., infrastaminal scales shorter than the corolla tube, papillae on both sides of corolla lobes, and the presence of stomata on the calyx) firmly indicate that $C$. umbellata var. dubia is within the variation range of $C$. desmouliniana, where we transfer it without further recognition at infraspecific level.

We could not reach a final decision about the taxonomic identity of C. umbellata var. desertorum described by Engelmann from Brazil (Piauí and Ceara) because of the poor quality of the only two herbarium specimens available (Appendix 2). Morphologically, this taxon appears to be quite similar to the C. umbellata plants encountered in Cape Verde islands, the Caribbean Archipelago, and N to NE littoral of South America, which are slightly different from those growing in Mexico and the U.S.A. This Atlantic form of $C$. umbellata has fewflowered, loose inflorescences, and often plants become darkbrownish upon drying (the U.S.-Mexican C. umbellata has many-flowered, dense inflorescences and plants commonly remain straw-yellow when dried). The only difference between the Atlantic form and C. umbellata var. desertorum resides in the more reduced, with fewer fimbria or rarely bifid infrastaminal scales encountered in the latter. Engelmann himself mentioned that a specimen of $C$. umbellata from Antigua (Wullschlagel $352, \mathrm{MO})$ was very similar to $C$. umbellata var. desertorum (Engelmann, 1859). In view of this unresolved issue, we have not distinguished a new variety of $C$. umbellata from the Pacific, and we maintained C. umbellata var. desertorum until more plants can be collected and studied from Brazil. 


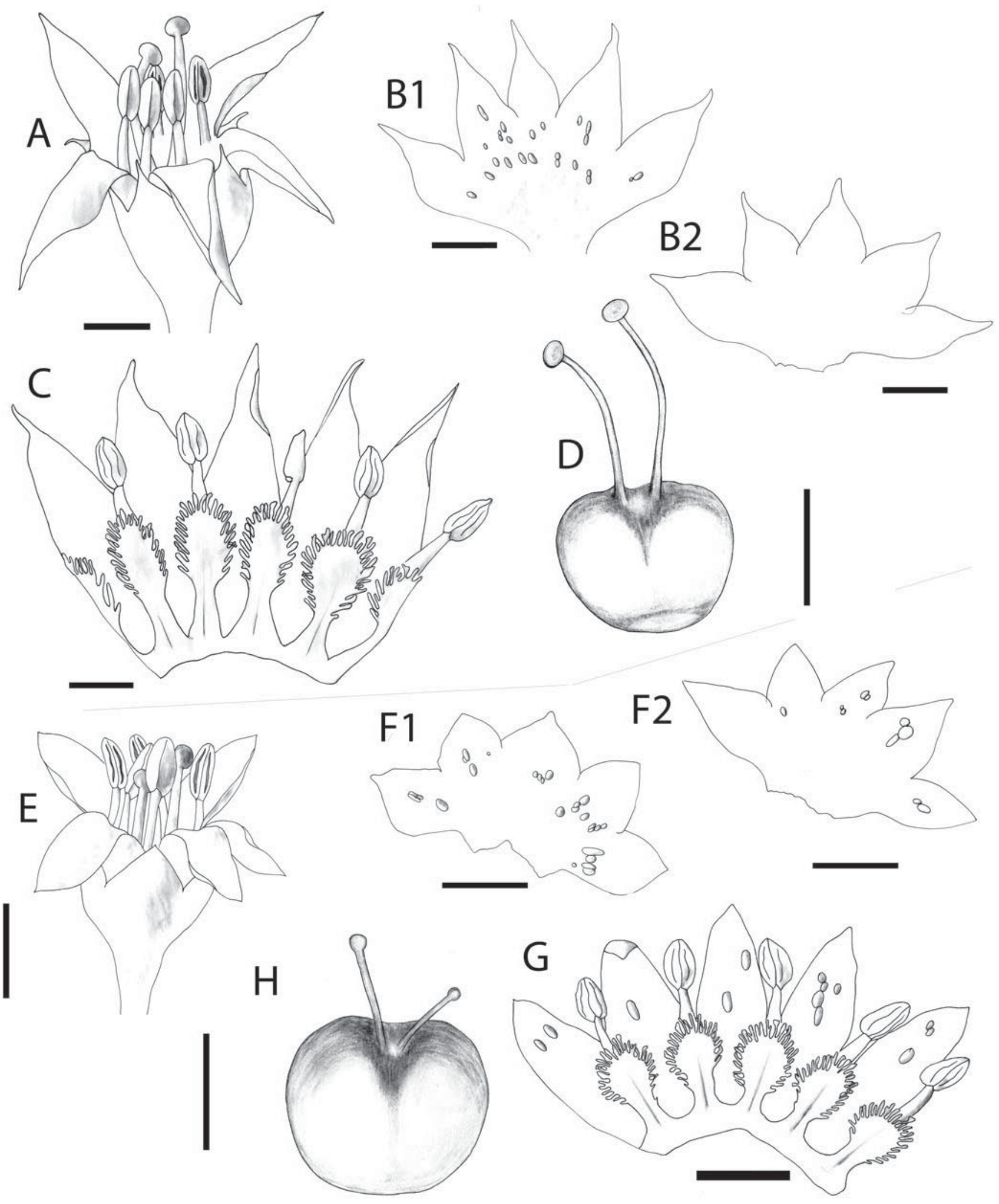

Fig. 5. A-D, Cuscuta legitima: A, Flower; B1-B2, calyx variation; C, corolla dissected; D, gynoecium. E-H, C. umbellata (var. umbellata): E, Flower; F1-F2, calyx variation; G, corolla dissected; H, gynoecium. Bars: $1 \mathrm{~mm}$. 
Late and occasionally irregular dehiscence of capsules is another subtle morphological difference that distinguishes the Atlantic form of C. umbellata from those that grow in Mexico and the U.S.A., in which capsules dehisce by a regular circular line even when they are still immature. The late dehiscence of capsules represents also the only character that separates the Atlantic C. umbellata from the morphologically very similar C. acuta and C. membranacea (see below). The decision to maintain these three species distinct is based on the evolutionary relationships observed among them (Figs. 2-3) and the complex reticulation patterns inferred (Fig. 4).

Cuscuta fasciculata, known from a single specimen (Yuncker, 1932), is morphologically identical to typical C. umbellata, and the former name is therefore considered a heterotypic synonym.

Cuscuta acuta and C. membranacea. - Since its description in 1859, C. acuta has been largely considered endemic to Galapagos Islands (Engelmann, 1859; Yuncker, 1921, 1932; Hunziker, 1949). Austin (1982) reported first C. acuta from mainland Ecuador and observed that " $C$. acuta is very similar to C. membranacea [...] and perhaps a single species is involved" (Austin, 1982). The doubt about the distinctiveness of the two species was prompted by the fact that the mainland Ecuador collection cited by Austin as a voucher of C. acuta (Asplund 5136, S, US) had been identified by Yuncker as " $C$. membranacea" (S) or "C. membranacea vel. aff." (US). As pointed out by Yuncker's identification (keep in mind that C. membranacea was described by Yuncker, 1939), these C. acuta plants are morphologically different from the "typical" C. acuta found in the Galapagos in that they exhibit some common features with C. membranacea. Similarly to C. membranacea, these dodders display a globose capsule with a small interstylar aperture and erect styles (C. acuta has a globose-depressed capsule with a relatively large interstylar aperture and divergent styles). Notwithstanding their apparent intermediacy, these mainland Ecuadorian C. acuta plants are slightly different morphologically from both C. membranacea and the "typical" C. acuta in their larger flowers, which remind more of $C$. legitima. We have found additional specimens of this continental C. acuta from Peru, where it has been generally identified as " $C$. umbellata". The difficulty to distinguish $C$. acuta and C. membranacea morphologically certainly makes the idea of a single species appealing, but this approach is unsupported by molecular data. Cuscuta membranacea is morphologically so close to C. acuta because it is most likely a hybrid species, and $C$. acuta is the putative maternal progenitor (see the plastid haplotype tree; Fig. 2, right; Fig. 4).

\section{TAXONOMIC TREATMENT}

\section{Identification Key for species of the Cuscuta umbellata clade}

1. Capsules indehiscent $\ldots \ldots \ldots \ldots \ldots \ldots \ldots \ldots 2$

1. Capsules dehiscent, irregularly dehiscent at the base or opening late. ............... 3
2. Flowers 2.5-3.6(-4.0) mm; calyx 1.6-2.3 mm; infrastaminal scales uniformly dense-fringed; styles slightly subulate

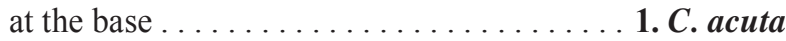

2. Flowers $2.0-2.8 \mathrm{~mm}$; calyx $1.2-1.6 \mathrm{~mm}$; infrastaminal scales distally fringed; styles evenly filiform . . . . . . .

.................... 8. C. membranacea

3. Calyx and corolla lobes lacerate. ...... 4. C. Iacerata

3. Calyx and corolla lobes entire ............4

4. Infrastaminal scales absent or represented by scarcely dentate ridges . . . . . . . . . . . . . 3. C. hyalina

4. Infrastaminal scales present, well developed, rarely bifid or with a few fimbria $\ldots \ldots \ldots \ldots \ldots \ldots \ldots$

5. Corolla tube cylindric . . . . . . . . . . . 6

5. Corolla tube campanulate. . . . . . . . . . . . . 10

6. Inflorescences dense, paniculiform-glomerulate; calyx lobes basally overlapping; capsules 2.9-4.0 $\times 3.0-3.5 \mathrm{~mm}$, not translucent; seeds $1.00-1.25 \times 0.65-0.80 \mathrm{~mm} . . .$. $\ldots \ldots \ldots \ldots \ldots \ldots \ldots$. . . . . odontolepis

6. Inflorescence loose, umbelliform or racemiform; calyx lobes not basally overlapping; capsules $1.3-2.2 \times 1.5-$ $2.3 \mathrm{~mm}$, translucent; seeds $0.6-0.9 \times 0.3-0.8 \mathrm{~mm} \ldots .7$

7. Flowers $5.0-7.5 \mathrm{~mm}$; corolla lobes ca. $1 / 2$ the tube ..... $\ldots \ldots \ldots \ldots \ldots \ldots \ldots \ldots$ 10. C. polyanthemos

7. Flowers $2.5-4.5(-5.0) \mathrm{mm}$; corolla lobes equaling the

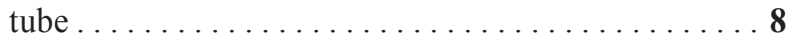

8. Flowers 5-merous; calyx lobes carinate; corolla lobes erect. . . . . . . . . . . . . . 11. C. tuberculata

8. Flowers (3-)4-merous; calyx lobes not carinate; corolla lobes spreading to reflexed. . . . . . . . . . . 9

9. Calyx equaling corolla tube; infrastaminal scales bridged at $0.1-0.3 \mathrm{~mm}$. . . . . . . . . . . . 7. C. liliputana

9. Calyx $1 / 3-1 / 2$ of the corolla tube; infrastaminal bridged at $0.4-0.8 \mathrm{~mm} \ldots \ldots \ldots \ldots \ldots \ldots$. . . . . . . . . . . . . . . . .

10. Infrastaminal scales ca. $3 / 4$ of the corolla tube . . . . . . .

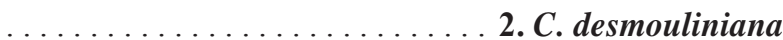

10. Infrastaminal scales equaling or slightly longer than the corolla tube . . . . . . . . . . . . . . 11

11. Flowers 4.0-5.5(-6.0) $\mathrm{mm}$; calyx lobes acuminate .... $\ldots \ldots \ldots \ldots \ldots \ldots \ldots \ldots \ldots$. . C. legitima

11. Flowers $2-3 \mathrm{~mm}$; calyx lobes obtuse to acute ....... ... . . . . . . . . . . . . . . . 12. C. umbellata

1. Cuscuta acuta Engelm. in Trans. Acad. Sci. St. Louis 1: 497. 1859 - Type: Ecuador, Galapagos Islands, Chatham [San Cristobal] Island, 1853, Andersson s.n. (holotype: K; isotypes: $\mathrm{GH}, \mathrm{MO}, \mathrm{IT}$ ).

Stems slender, yellow-orange. Inflorescences denseumbelliform, confluent; pedicels $0.6-3.0 \mathrm{~mm}$; bracts 1 at the base of clusters and $0-1$ at the base of pedicels, $1.5-2.8 \mathrm{~mm}$ long, triangular-ovate, margins entire, apex acuminate. Flowers 5-merous, 2.5-3.6(-4.0) mm, membranous, white when fresh, creamy-brown when dried; papillae absent, laticifers evident in the bracts, calyx, corolla, tips of infrastaminal scale fimbriae, and ovary, isolated or in rows, ovoid to elongate; calyx $1.6-2.3(-2.6) \mathrm{mm}$, straw-yellow to brown, not reticulate or shiny, campanulate, longer than corolla tube, divided ca. $2 / 3$ the length, tube $0.4-0.8 \mathrm{~mm}$, lobes (unequal) $0.7-1.5 \mathrm{~mm}$, 
not basally overlapping, ovate-triangular, not carinate, margins entire, apex acuminate; corolla $1.8-3.3(-3.8) \mathrm{mm}$, tube 0.9-1.7 mm, campanulate, lobes $0.9-1.9 \mathrm{~mm}$, initially erect, later reflexed, ca. as long or slightly longer than the tube, ovatelanceolate, margins entire, apex acute to acuminate, straight; stamens exserted, shorter than the lobes, anthers $0.33-0.40 \times$ $0.20-0.25 \mathrm{~mm}$, broadly ovate to oblong, filaments $0.4-0.7 \mathrm{~mm}$; infrastaminal scales extremely thin, 0.9-1.7 mm long, equaling the tube, bridged at $0.15-0.30 \mathrm{~mm}$, obovate to oblong, uniformly dense-fringed, fimbriae $0.15-0.30 \mathrm{~mm}$; styles $0.4-1.1 \mathrm{~mm}$, shorter or equaling the ovary, slightly subulate at the base, filiform in the rest. Capsules indehiscent, 1.7-2.5 × 0.9-1.4 mm, globose-depressed, thickened around the moderate interstylar aperture, translucent, surrounded by the withered corolla. Seeds 4 per capsule, $0.7-1.2 \times 0.7-1.0 \mathrm{~mm}$, subround to round.

Distribution and ecology. - Galapagos Islands and the Pacific Coast of Ecuador and Peru; flowering Jan.-July; elevation 40-160 m; hosts: Alternanthera, Coldenia, Boerhavia, Euphorbia, Ipomoea, Pectis, Portulaca, Rhynchosia and Tribulus.

2. Cuscuta desmouliniana Yunck. in Illinois Biol. Monogr. 6(2-3): 40. $1921 \equiv C$. desmouliniana Yuncker var. attenuiloba Yunck. in Illinois Biol. Monogr. 6 (2-3): 41. 1921 - Type: Mexico. Sonora, hills near Altar, 26 Aug 1884, Pringle 105 (holotype: NY; isotypes: G, GH, IND, MEXU, MO, NY, US). Yuncker (1921: 41) mentioned that "this specimen [Pringle 105] seems to be a mixture of the following two distinguishable varieties ("typical" and "attenuiloba"). Figure 1F-I.

= Cuscuta umbellata var. dubia Yunck. in Illinois Biol. Monogr. 6(2-3): 43. 1921 - Type: Mexico. Sonora, Guayamas, 22 Feb 1904, Palmer 1209 (holotype: US).

Stems slender, yellow-orange. Inflorescences loose, umbellate, often confluent; pedicels $1-5 \mathrm{~mm}$; bracts 1 at the base of clusters and $0-1$ at the base of pedicels, $0.6-1.0 \mathrm{~mm}$ long, ovate-lanceolate, margins entire, apex acute. Flowers 5-merous, 2-3 mm, membranous, white when fresh, creamy-white when dried, papillae usually present on the pedicels, calyx, abaxial and adaxial epidermis of corolla lobes, and sometimes on the ovary/capsule; laticifers not visible or hardly so in the midveins of corolla lobes, elongate; calyx $0.6-1.2 \mathrm{~mm}$, brownish-yellow, \pm reticulate or shiny, campanulate, equaling or somewhat longer than the corolla tube, divided 1/3-1/2 the length, tube $0.25-0.50 \mathrm{~mm}$, lobes $0.50-0.76 \mathrm{~mm}$, not overlapping, triangular-ovate to lanceolate, weakly to distinctly carinate, with small dome-like multicellular projections on the midveins, margins irregular, \pm revolute at the base and forming angled sinuses especially when lobes are triangular ovate, apex acute to acuminate somewhat reflexed; corolla $1.5-$ $2.9 \mathrm{~mm}$, tube narrow-campanulate, $0.8-1.5 \mathrm{~mm}$, lobes $1.0-1.5$ $\mathrm{mm}$, initially erect, later spreading or reflexed, slightly longer than the tube, lanceolate, margins entire to irregular, sometimes involute upon drying and appearing very narrow, apex acute, \pm incurved; stamens short-exserted, shorter than corolla lobes, anthers $0.4-0.6 \times 0.2-0.3 \mathrm{~mm}$, ovate to oblong, filaments $0.4-0.7 \mathrm{~mm}$; infrastaminal scales $0.6-1.0 \mathrm{~mm}$ long, ca. $3 / 4 \mathrm{of}$ the corolla tube, bridged at $0.1-0.2 \mathrm{~mm}$, oblong to spathulate, short-fringed, fimbriae $0.05-0.15 \mathrm{~mm}$; styles $1.2-2.1 \mathrm{~mm}$, longer than the ovary, evenly filiform. Capsules circumscissile, $1.2-2.0 \times 0.9-1.7 \mathrm{~mm}$, globose to globose-depressed, slightly thickened and risen, or with a few protuberances around the inconspicuous interstylar aperture, translucent, capped by the withered corolla. Seeds $2-4$ per capsule, $0.75-0.90 \times 0.70-$ $0.80 \mathrm{~mm}$, subrotund to broadly elliptic.

Distribution and ecology. - Mexico: Baja California and Sonora; flowering Aug.-Sep.; Dec.-Mar.; elevation 30-300 m; hosts: usually on Chamaesyce, rarely on Boerhaavia or Pectis.

3. Cuscuta hyalina Roth, Nov. Pl. Sp.: 100. 1821 - Type: India “orientale," Heyne s.n. (holotype: B, apparently destroyed; isotype: $\mathrm{K}$ ).

=C. epitribulum Schinz in Bull. Herb. Boissier, sér. 2, 1: 880 . 1901 - Type: South West Africa, Namibia, Okomita, Dinter 506 (holotype: Z).

Stems slender, yellow-orange. Inflorescences dense to loose, umbelliform, confluent; pedicels 2-4 mm; bracts 1 at the base of clusters and $0-1$ at the base of pedicels, 2.0-3.6 mm long, narrow triangular lanceolate, margins entire, apex long-acuminate. Flowers 5-merous, 2.5-4.2 mm, membranous, creamywhite when fresh, creamy-yellow when dried; papillae absent, laticifers evident in the bracts, calyx, corolla lobes, and ovary, isolated, ovoid to elongate; calyx 2.0-3.2 mm, straw-yellow, not reticulate, slightly shiny, campanulate, much longer than corolla tube, divided $1 / 2-2 / 3$ the length, tube $0.9-1.4 \mathrm{~mm}$, lobes $1.5-2.0 \mathrm{~mm}$, not basally overlapping, triangular-lanceolate, not carinate, margins entire, apex acuminate, \pm reflexed; corolla 2.3-4.0 mm, tube 1.0-1.4 mm, campanulate, lobes $1.5-2.5 \mathrm{~mm}$, initially erect, later reflexed, longer than the tube, triangularlanceolate, margins entire, apex acuminate, straight; stamens exserted, shorter than the lobes, anthers $0.4-0.6 \times 0.3-0.4 \mathrm{~mm}$, elliptic, filaments $0.5-0.7 \mathrm{~mm}$; infrastaminal scales absent or represented by scarcely dentate ridges; styles $0.9-2.0 \mathrm{~mm}$, equaling or longer than the ovary, evenly filiform. Capsules circumscissile, 2.0-3.0 × 2.0-2.5 mm, globose, thickened and slightly risen around the inconspicuous interstylar aperture, translucent, surrounded by the withered corolla. Seeds $2-4$ per capsule, $1.3-1.5 \times 0.9-1.1 \mathrm{~mm}$, elliptic.

Note. - Cuscuta hyalina var. nubiana Yunck. in Mem. Torrey Bot. Club 18(2): 236. 1932 [Type: Sudan, Gef. bei Suakin. Nubische Küste, Jun 1864, Schweinfurth 964 (isotype: K)] has flowers with scales occasionally represented by ridges.

Distribution and ecology. - Asia: Pakistan and India; Africa: Ethiopia, Sudan, Botswana, Zimbabwe, Uganda, Kenya, Ruanda, Burundi, South Africa, Namibia; flowering July-Nov.; Dec.-Mar.; 700-1500 m; hosts: Cyperus bulbosus, Portulaca sp., Tribulus terrestris, and Zaleya pentandra.

4. Cuscuta lacerata Yunck. in Illinois Biol. Monogr. 6 (2-3): 44. 1921 - Type: Mexico. Oaxaca, Cuicatlan, 15 Jul 1895, L.E. Smith 406 (holotype: GH).

Stems slender, yellow-orange. Inflorescences loose, umbellate, often confluent; pedicels $1.5-4.0 \mathrm{~mm}$; bracts 1 at the base of clusters and $0-1$ at the base of pedicels, $0.6-1.2 \mathrm{~mm}$ long, lanceolate, margins entire or irregularly dentate, apex 
acuminate. Flowers 5-merous, 3.0-4.4 mm, membranous, white when fresh, creamy-white when dried, papillae absent; laticifers visible in the calyx and corolla lobes, isolated, ovoid to elongate; calyx $1.8-2.4 \mathrm{~mm}$, yellow, \pm reticulate or shiny, campanulate, longer than the corolla tube, divided $1 / 4-1 / 3$ the length, tube $0.3-0.6 \mathrm{~mm}$, lobes $1.5-1.8 \mathrm{~mm}$, not overlapping, lanceolate, not carinate, not forming angled sinuses, margins with a few irregular teeth (especially toward apex), apex long acuminate, reflexed; corolla $2.8-4.2 \mathrm{~mm}$, tube $1.0-1.4 \mathrm{~mm}$, campanulate, lobes $2.0-1.6 \mathrm{~mm}$, initially erect, later spreading or reflexed, longer than the tube, linear, margins with a few large, irregular teeth, sometimes involute upon drying and appearing very narrow, apex long-acuminate, capillary; stamens exserted, shorter than corolla lobes, anthers $0.5-0.6 \times 0.2-$ $0.3 \mathrm{~mm}$, ovate to oblong, filaments $0.6-1.0 \mathrm{~mm}$; infrastaminal scales $1.0-1.6 \mathrm{~mm}$ long, equaling or longer than corolla tube, bridged at $0.16-0.25 \mathrm{~mm}$, oblong-spathulate, medium-fringed, fimbriae $0.12-0.25 \mathrm{~mm}$; styles $1.8-2.4 \mathrm{~mm}$, longer than the ovary, evenly filiform. Capsules circumscissile, 1.2-1.6 $\times$ $1.0-1.7 \mathrm{~mm}$, globose, with a ring of protuberances around the inconspicuous interstylar aperture, translucent, capped by the withered corolla. Seeds $1-4$ per capsule, $0.9-1.0 \times 0.8-0.9 \mathrm{~mm}$, angled, subrotund.

Distribution and ecology. - Known only from the type collection from Cuicatlan, Mexico; flowering July; elevation and host unknown.

5. Cuscuta legitima Costea \& Stefanović, sp. nov. - Type: Mexico. Sonora: Northwest side of Río Yaqui at MEX 15 near Esperanza, ca. $9 \mathrm{~km}$ north of Ciudad Obregón, $27^{\circ} 35^{\prime} 45^{\prime \prime} \mathrm{N} 109^{\circ} 56^{\prime} \mathrm{W}$, ca. 40 m elevation, locally common parasite on Boerhavia coccinea (Nyctaginaceae), flowers white, stems yellow, 10 Sep 1994, Van Devender 94-458 \& al. (holotype: ARIZ; isotypes: ASU, MEXU, UC, UCR, WLU). Figure 5A-D.

= Cuscuta californica var. reflexa J.M. Coulter in Contr. U.S. Natl. Herb. 1: 45. 1890; 2: 295. $1892 \equiv$ Cuscuta umbellata var. reflexa (J.M. Coulter) Yunck. in Illinois Biol. Monogr. 6(2-3): 42. 1921 - Type: U.S.A. Texas, Roma, 1889, Nealley 338 (holotype: US; isotype: GH).

Cuscutae umbellatae similis, sed flores 4.0-5.5(-6.0) $\mathrm{mm}$ longi; calyx 2.5-3.2 mm longus, lobis acuminatibus; corolla 3.8-5.2(-5.6) mm longa. Cuscutae acutae et C. membranacea similis, sed floribus majoribus et capsulae dehiscentibus.

Stems slender, yellow-orange. Inflorescences dense to loose, umbelliform, confluent; pedicels $2-10 \mathrm{~mm}$; bracts 1 at the base of clusters and $0-1$ at the base of pedicels, $2.0-3.6 \mathrm{~mm}$ long, broadly triangular-ovate, margins entire, apex acuminate. Flowers 5-merous, 4.0-5.5(-6.0) mm, membranous, white when fresh, creamy-white when dried; papillae absent, laticifers evident in the bracts, calyx, corolla, tips of infrastaminal scale fimbriae, and ovary, isolated, ovoid; calyx $2.5-3.2 \mathrm{~mm}$, strawyellow, finely reticulate, slightly shiny, campanulate, longer than corolla tube, divided ca. $2 / 3$ the length, tube $0.6-1.0 \mathrm{~mm}$, lobes $1.5-2.2 \mathrm{~mm}$, not basally overlapping, ovate-lanceolate, not carinate, margins entire, apex acuminate; corolla $3.8-5.2(-5.6) \mathrm{mm}$, tube 1.6-2.1 mm, campanulate, lobes $1.8-3.0 \mathrm{~mm}$, initially erect, later reflexed, longer than the tube, linear-lanceolate, margins entire, apex acuminate, straight; stamens exserted, shorter than the lobes, anthers $0.50-0.70 \times 0.24-0.36 \mathrm{~mm}$, elliptic to oblong, filaments $0.6-1.0 \mathrm{~mm}$; infrastaminal scales $1.8-2.2 \mathrm{~mm}$ long, equaling or slightly longer than the tube, bridged at $0.2-0.4 \mathrm{~mm}$, spathulate to obovate, uniformly dense-fringed, fimbriae 0.2 $0.5 \mathrm{~mm}$; styles $0.9-2.5 \mathrm{~mm}$, longer than the ovary, evenly filiform. Capsules circumscissile, 2-3 × 1-2 mm, depressed, irregularly thickened and slightly risen around the inconspicuous interstylar aperture, translucent, surrounded or capped by the withered corolla. Seeds $2-4$ per capsule, $0.9-1.2 \times 0.8-0.9 \mathrm{~mm}$, broadly elliptic to subround.

Distribution and ecology. - U.S.A. and Mexico; flowering Aug.-Nov.; elevation 40-1200 m; hosts: Allionia, Amaranthus, Boerhavia, Chamaesaracha, Evolvulus, Kallstroemia, Salsola, Solanum, Tidestromia, Trianthema, Tribulus.

6. Cuscuta leptantha Engelm. in Trans. Acad. Sci. St. Louis 1: 489.1859 - Type: U.S.A. Texas, Oct 1849, Wright 522 (holotype: MO; isotype: US). Figure 1D.

$=$ Cuscuta palmeri S. Watson in Proc. Amer. Acad. Arts 24: 64. 1889 - Type: Mexico, Baja California, 1887, Palmer 544 (holotype: NY; isotypes: US, GH).

Stems slender, yellow-orange. Inflorescences loose, umbellate, confluent; pedicels (1-)2-7 mm; bracts 1 at the base of clusters and $0-1$ at the base of pedicels, $0.75-1.00 \mathrm{~mm}$ long, triangular ovate, margins entire, apex acute. Flowers 4-merous, 3.5-4.5(-5.0) mm, membranous, white when fresh, creamywhite when dried, papillae usually present on the pedicels and perianth; laticifers not visible; calyx $1.5-1.8 \mathrm{~mm}$, strawyellow, not reticulate or shiny, campanulate, $1 / 3-1 / 2$ of the corolla tube, divided ca. $1 / 2$ the length, the tube $0.5-0.8 \mathrm{~mm}$, lobes $0.8-1.0 \mathrm{~mm}$, not basally overlapping, triangular-ovate, not carinate, margins entire, apex acute; corolla $3-4 \mathrm{~mm}$, tube $1.5-2.5 \mathrm{~mm}$, cylindric, lobes $1.5-2.0 \mathrm{~mm}$, initially erect, later spreading or reflexed, as long as the tube, lanceolate, margins entire often involute upon drying and corolla lobes appearing narrow, apex acute, \pm cucullate; stamens short-exserted, shorter than corolla lobes, anthers $0.40-0.60 \times 0.35-0.45 \mathrm{~mm}$, subround to broadly elliptic, filaments $0.3-0.6 \mathrm{~mm}$; infrastaminal scales $1.3-2.1 \mathrm{~mm}$ long, ca. $1 / 2$ of the corolla tube, bridged at $0.4-0.8 \mathrm{~mm}$, oblong, uniformly short-fringed, fimbriae 0.05 $0.15 \mathrm{~mm}$; styles $1.2-2.1 \mathrm{~mm}$, longer than the ovary, evenly filiform. Capsules circumscissile, 1.5-2.0 × 1.6-1.9 mm, globose, slightly thickened and risen or with a few protuberances around the inconspicuous interstylar aperture, translucent, capped by the withered corolla. Seeds $2-4$ per capsule, $0.75-0.90 \times 0.70$ $0.80 \mathrm{~mm}$, angled, subrotund to broadly elliptic.

Distribution and ecology. - U.S.A.: Texas, New Mexico; Mexico: Baja California, Sonora, Sinaloa; flowering Nov.May; elevation 10-125 m; host: Chamaesyce sp.

7. Cuscuta liliputana Costea \& Stefanović in Botany 86(8): 802. 2008 - Type: U.S.A. New Mexico, Sierra Co., 3 mi S of Hillsboro, $5500 \mathrm{ft}, 9$ Sep 1904, O.B. Metcalfe 1290 (holotype: UNM; isotypes: ARIZ, MO, NMC, NY, UNM, WLU). 
Stems slender, yellow to pale orange. Inflorescences loose, umbelliform; pedicels (1-)2-3(-5) mm; bracts 1 at the base of clusters and $0-1$ at the base of pedicels, $0.7-1.0 \mathrm{~mm}$ long, ovatelanceolate, margins entire, apex acute. Flowers (3-)4-merous, 2.8-4.0 mm, fleshy, white when fresh, creamy when dried; papillae usually present on pedicels, calyx and corolla; laticifers hardly visible only in the midveins of the corolla lobes, elongate; calyx 1.3-1.7 mm, straw-yellow, somewhat reticulate and shiny, equaling the corolla tube, divided ca. 3/4 the length, tube $0.3-0.7 \mathrm{~mm}$, cylindric, lobes $1.00-1.35 \mathrm{~mm}$, not basally overlapping, ovate-triangular, not carinate but sometimes with multicellular protuberances bearing stomata on the midveins, apex acute to acuminate, margins entire; corolla $3.0-3.6 \mathrm{~mm}$, tube $1.5-2.0 \mathrm{~mm}$, cylindric, lobes $1.30-1.65 \mathrm{~mm}$, initially erect, later spreading and reflexed, equaling the tube, lanceolate, margins entire, apex acute straight; stamens exserted, shorter than the lobes, anthers $0.35-0.50 \times 0.20-0.35 \mathrm{~mm}$, broadly to narrow elliptic, filaments $0.5-0.8 \mathrm{~mm}$; infrastaminal scales $0.6-0.8 \mathrm{~mm}$ long, $1 / 4-1 / 2$ of the corolla tube, bridged at $0.1-$ $0.3 \mathrm{~mm}$, truncate to slightly obovate, distally fringed, fimbriae $0.10-0.18 \mathrm{~mm}$; styles $0.8-2.5 \mathrm{~mm}$, longer than the ovary, evenly filiform. Capsules circumscissile, $1.50-2.20 \times 0.75-1.50 \mathrm{~mm}$, globose to globose-depressed, thicken and slightly risen, or with 2-4 protuberances around the small interstylar aperture, translucent, capped by the withered corolla. Seeds $2-4$ per capsule, $0.80-1.15 \times 0.70-0.85 \mathrm{~mm}$, subrotund to broadly elliptic.

Distribution and ecology. - U.S.A.: Southern New Mexico, Arizona, and SW Texas; flowering July-Nov.; Nov.-Feb.; elevation 30-1700 m; host: Chamaesyce sp.

8. Cuscuta membranacea Yunck. in Lilloa 4: 452. 1939 Type: Argentina. Departamento Trancas, Tucumán, Tapia, $600 \mathrm{~m}$, [the host is Amaranthus muricatus], 29 Nov 1918, Schreiter 983 (holotype: LIL).

Stems slender, orange. Inflorescences dense, umbelliform; pedicels $1-3 \mathrm{~mm}$; bracts 1 at the base of clusters and $0-1$ at the base of pedicels, 1.6-2.6 mm long, triangular-ovate, margins entire, apex acute to acuminate. Flowers (4-)5-merous, 2.0$2.8 \mathrm{~mm}$, membranous, white when fresh, creamy-brown when dried; papillae absent, laticifers evident in the bracts, calyx, corolla, and ovary, isolated ovoid to elongate; calyx $1.2-1.6 \mathrm{~mm}$, straw-yellow to brown, not reticulate or shiny, campanulate, longer than corolla tube, divided $1 / 3-1 / 2$ the length, tube 0.4 $0.8 \mathrm{~mm}$, lobes [unequal] $0.7-1.2 \mathrm{~mm}$, not basally overlapping, ovate-triangular, not carinate, margins entire, apex acute to apiculate; corolla $1.5-2.5 \mathrm{~mm}$, tube $0.9-1.3 \mathrm{~mm}$, campanulate, lobes $0.7-1.3 \mathrm{~mm}$, initially erect, later reflexed, ca. as long as the tube, triangular-lanceolate, margins entire, apex acute to acuminate, initially cucullate, later straight; stamens exserted, shorter than the lobes, anthers $0.3-0.5 \times 0.2-0.3 \mathrm{~mm}$, broadly ovate to elliptic, filaments $0.4-0.7 \mathrm{~mm}$; infrastaminal scales extremely thin, $0.9-1.4 \mathrm{~mm}$ long, equaling or longer than the tube, bridged at $0.15-0.30 \mathrm{~mm}$, oblong, distally fringed, fimbriae $0.10-0.25 \mathrm{~mm}$; styles $0.4-1.0 \mathrm{~mm}$, shorter than the ovary, evenly filiform. Capsules indehiscent, 1.9-2.5 × 0.9-2.0 mm, globose with irregular thickenings raised around the small interstylar aperture, translucent, surrounded by the withered corolla.
Seeds 2-4 per capsule, $0.90-1.26 \times 0.80-1.10 \mathrm{~mm}$, subround to broadly elliptic.

Distribution and ecology. - Argentina; flowering: Nov.Mar.; elevation 500-1575 m; hosts: Amaranthus, Boerhavia, Gomphrena, Kallstroemia, Nicotiana, Portulaca.

9. Cuscuta odontolepis Engelm. in Trans. Acad. Sci. St. Louis 1: 486. 1859 - Type: U.S.A. Arizona, Santa Rita Mts., south of Tucson, 1851-1852, Wright 1624 (holotype: MO; isotypes: GH, K, NY). Figure 1A.

Stems slender, yellowish. Inflorescences dense, paniculiform-glomerulate; pedicels to $1 \mathrm{~mm}$; bracts 1 at the base of cymes and $0-1$ at the base of pedicels/flowers, 2-3 $\mathrm{mm}$ long, subround to broadly ovate, margins entire, apex acute to short acuminate. Flowers 5-merous, 4.5-5.0 mm, membranous, white when fresh, creamy-white when dried; papillae present on the bracts, calyx and corolla lobes; laticifers poorly visible only in the corolla lobes, isolated, elongated; calyx $2.0-2.5 \mathrm{~mm}$, straw-yellow, finely reticulate, not shiny, campanulate, 1/2-3/4 as long as the corolla tube, divided ca. $2 / 3$, tube $0.5-0.9 \mathrm{~mm}$, lobes $1.3-1.5 \mathrm{~mm}$, ovate-triangular, outer 2 lobes auriculate, basally overlapping, not carinate, margins entire, apex acute to short acuminate; corolla $3.5-4.5 \mathrm{~mm}$, tube $2.2-2.8 \mathrm{~mm}$, cylindric, lobes 1.6-2.0 mm, initially erect, later reflexed, ovatetriangular, margins entire, basally overlapping, apex acute to short acuminate, straight; stamens barely exserted, shorter than corolla lobes, anthers $0.70-1.10 \times 0.25-3.00 \mathrm{~mm}$, oblong, filaments $0.3-0.7 \mathrm{~mm}$; infrastaminal scales $2.0-2.5 \mathrm{~mm}$ long, $1 / 2$ to equaling the corolla tube, bridged at $0.25-0.50 \mathrm{~mm}$, oblong-spathulate to obovate, rounded, fringed in the distal $1 / 2$, fimbriae $0.2-0.3 \mathrm{~mm}$; styles $2.8-4.0 \mathrm{~mm}$, longer than the ovary, evenly filiform. Capsules circumscissile, $2.9-4.0 \times 3.0-$ $3.5 \mathrm{~mm}$, globose to globose-depressed, thickened and raised around the inconspicuous interstylar aperture, translucent, loosely surrounded and capped by the withered corolla. Seeds 3-4 per capsule, $1.00-1.25 \times 0.65-0.80 \mathrm{~mm}$, broadly elliptic.

Distribution and ecology. - U.S.A.: Arizona; Mexico: Chihuahua and Sonora; flowering Aug.-Oct.; elevation 9001500 m; host: Amaranthus sp.

10. Cuscuta polyanthemos Schaffner ex Yunck. in Illinois Biol. Monogr. 6(2-3): 46. 1921 - Type: Mexico. Sinaloa, Culiacán, Schaffner s.n. (holotype: NY).

Stems slender, yellow. Inflorescences loose, corymbiform or umbellate, often confluent; pedicels 4-15(-20 mm); bracts 1 at the base of clusters, $0.8-1.2 \mathrm{~mm}$ long, ovate triangular to lanceolate, margins entire, apex acute. Flowers 5-merous, 5.0-7.5 mm, membranous, white both when fresh and dry, papillae present on the corolla lobes; laticifers not visible; calyx 2.0-2.5 mm, straw-yellow, not reticulate or shiny, cylindric campanulate, $1 / 4-1 / 3$ of the corolla tube, divided ca. $1 / 3$ the length, the tube $0.4-0.8 \mathrm{~mm}$, lobes $1.5-2.0 \mathrm{~mm}$, not basally overlapping, triangular-ovate to lanceolate, not carinate but with small protuberances on the midveins, margins entire, apex acute; corolla 5-7 mm, tube 4-5 mm, cylindric, lobes $2.0-$ $2.5 \mathrm{~mm}$, initially erect, later spreading or reflexed, $1 / 2$ as long as the tube, triangular lanceolate, margins entire, apex acute to 
acuminate; stamens short-exserted, shorter than corolla lobes, anthers $0.60-1.00 \times 0.35-0.45 \mathrm{~mm}$, oblong elliptic, filaments $0.5-0.8 \mathrm{~mm}$; infrastaminal scales $2.0-2.5 \mathrm{~mm}$ long, bridged at $0.25-0.40 \mathrm{~mm}, 1 / 3-1 / 2$ of the corolla tube, oblong, sparsely short-fringed, fimbriae $0.05-0.20 \mathrm{~mm}$; styles $4-5 \mathrm{~mm}$, much longer than the ovary, evenly filiform. Capsules circumscissile, $1.0-2.0 \times 0.8-1.2 \mathrm{~mm}$, globose, thickened and risen around the inconspicuous interstylar aperture, translucent, capped by the withered corolla. Seeds 2-3 per capsule, 1.00-1.20 × $0.70-0.85 \mathrm{~mm}$, subrotund to broadly ovate.

Distribution and ecology. - Mexico: Sonora and Sinaloa; flowering Aug.-Sep.; elevation ca. 635 m; host: Chamaesyce sp.

11. Cuscuta tuberculata Brandegee in Univ. Calif. Publ. Bot. 3: 389. 1909 - Type: Mexico, 6 Mar 1889, Brandegee s.n. (holotype: UC). Figure 1E.

Stems filiform, yellow-orange. Inflorescences loose, umbelliform or racemiform, confluent; pedicels $2-3(-5) \mathrm{mm}$; bracts 1 at the base of clusters, usually absent at the base of peduncles, $0.50-0.75 \mathrm{~mm}$ long, ovate-lanceolate, margins entire, apex acute. Flowers 5-merous, $2.5-4.0 \mathrm{~mm}$, membranous, white-creamy when fresh, creamy when dried; papillae present especially at the base of the corolla tube, laticifers barely visible in the corolla, isolated, ovoid to elongated; calyx $0.5-1.5 \mathrm{~mm}$, yellow, not or finely reticulate, \pm glossy, campanulate-angular, $1 / 3-1 / 2$ as long as the corolla tube, divided almost to the base, tube $0.2-0.5 \mathrm{~mm}$, lobes $1.0-1.3 \mathrm{~mm}$, not basally overlapping, triangular to lanceolate, carinate and with multicellular protuberances bearing stomata on the midveins, margins entire, acute to acuminate; corolla $2.0-3.5 \mathrm{~mm}$, tube $1.5-2.2 \mathrm{~mm}$, cylindric, lobes $1.2-2.0 \mathrm{~mm}$, erect, about equaling the tube, triangular lanceolate, margins entire, apex acute, straight; stamens barely exserted, shorter to almost equaling corolla lobes, anthers $0.50-0.80 \times 0.25-0.30 \mathrm{~mm}$, ovate to oblong, filaments $0.4-0.7 \mathrm{~mm}$; infrastaminal scales $0.5-1.0 \mathrm{~mm}$ long, ca. $1 / 2$ the length of the corolla tube, bridged at $0.3-0.5 \mathrm{~mm}$, ovate, uniformly short-fringed, fimbriae $0.05-0.15 \mathrm{~mm}$; styles 1.5-3.0 mm, longer than the ovary, evenly filiform. Capsules circumscissile, globose, $1.3-2.2 \times 1.0-2.3 \mathrm{~mm}$, slightly thickened and risen around the small interstylar aperture, translucent, capped by the withered corolla. Seeds usually 4 per capsule, $0.6-0.9 \times 0.3-0.5 \mathrm{~mm}$, elliptic-oblong.

Distribution and ecology. - U.S.A: Arizona and New Mexico; Mexico: Baja California and Sonora; flowering Aug.-Nov.; elevation 70-700 m; host usually Boerhavia, rarely Amaranthus and genera of Euphorbiaceae.

12. Cuscuta umbellata Kunth, Nov. Gen. Sp. Pl. 3 [folio]: 95. 1818 - Type: [Mexico.] Crescit in Nova Hispania, inter Querretaro et Salamanca, Humboldt s.n. (lectotype: MO, designated by Yuncker, 1932; isolectotype: P). Figures $1 \mathrm{~B}-\mathrm{C}$ and $5 \mathrm{E}-\mathrm{H}$.

$=$ C. fasciculata Yunck. in Mem. Torrey Bot. Club 18: 240 . 1932 - Type: U.S.A. New Mexico, Santa Fe, 26 Jul 1918, Bro. Bertraud 48 (holotype: US; isotype: UNM).

Stems slender, yellow-orange. Inflorescences dense to loose, umbelliform, confluent; pedicels $2-10 \mathrm{~mm}$; bracts 1 at the base of clusters, usually absent at the base of pedicels, 0.5-2.0 $\mathrm{mm}$ long, triangular-ovate, margins entire, apex acute. Flowers 5-merous, 2-3 mm, membranous, white when fresh, creamy-white or dark brown when dried; papillae sometimes present but only on the adaxial face of corolla lobes; laticifers evident in the bracts, calyx, corolla, tips of infrastaminal scale fimbriae, and ovary, isolated, ovoid; calyx $0.8-1.4 \mathrm{~mm}$, strawyellow, finely reticulate, slightly shiny, campanulate, equaling the corolla tube, divided ca. $2 / 3$ the length, tube $0.25-0.60 \mathrm{~mm}$, lobes $0.5-0.9 \mathrm{~mm}$, not basally overlapping, broadly triangular-ovate, not carinate, margins entire, apex obtuse to acute, initially cucullate, later straight; corolla $2.0-2.5 \mathrm{~mm}$, tube $0.6-1.2 \mathrm{~mm}$, campanulate, lobes $0.8-1.5 \mathrm{~mm}$, initially erect, later reflexed, equaling or slightly longer than the tube, oblong to lanceolate, margins entire, apex obtuse to acute, straight; stamens exserted, shorter than the lobes, anthers $0.40-0.60$ $\times 0.24-0.30 \mathrm{~mm}$, elliptic to oblong, filaments $0.4-0.7 \mathrm{~mm}$; infrastaminal scales $0.8-1.2 \mathrm{~mm}$ long, equaling or slightly longer than the tube, bridged at ca. $0.1 \mathrm{~mm}$, subspathulate to obovate, uniformly dense-fringed, fimbriae $0.15-0.32 \mathrm{~mm}$; styles $0.8-1.7 \mathrm{~mm}$, equaling or longer than the ovary, evenly filiform. Capsules circumscissile, $1.0-2.5 \times 0.5-1.2 \mathrm{~mm}$, depressed, irregularly thickened and slightly risen around the inconspicuous interstylar aperture, translucent, surrounded or capped by the withered corolla. Seeds 4 per capsule, $0.80-1.20$ $\times 0.65-0.80 \mathrm{~mm}$, broadly elliptic to subround.

Note. - Cuscuta umbellata var. desertorum Engelm. in Trans. Acad. Sci. St. Louis 1(3): 488. 1859, differs in having more reduced infrastaminal scales, with fewer fimbriae (rarely bifid, see the holotype morphology gallery in Costea, 2007 onwards).

Distribution and ecology. - North and Central America: U.S.A, Mexico, Panama; Caribbean: Cuba, Haiti, Jamaica, Turks and Caicos, Virgin Islands; South America: Venezuela, Guayana, Suriname, Brazil; Cape Verde. Flowering June-Dec.; Dec.-Mar.; elevation 10-2700 m; sometimes on saline soils; hosts: Acleisanthes, Alternanthera, Allionia, Amaranthus, Atriplex, Boerhavia, Gilia, Iresine, Kallstroemia, Phyloxerus, Sesuvium, Salsola, Selinocarpus, Suaeda, Tidestromia, Trianthema, Tribulus.

\section{ACKNOWLEDGEMENTS}

The authors thank the curators/directors of AAU, ALTA, ARIZ, ASU, B, BAB, BOL, BRIT, CANB, CAS, CEN, CHR, CHSC, CIIDIR, CIMI, CTES, DAO, F, G, GH, H, HUFU, IAC, IEB, IND, J, JEPS, LL, LP, LPB, LPS, K, MEL, MERL, MEXU, MICH, MO, NMC, NY, OAC, OKLA, OSC, OXF, PACA, PRE, QCNE, QFA, P, PACA, RB, RSA, SAM, S, SD, SGO, SI, SPF, TEX, TRT, TRTE, UA, UB, UBC, UCR, UCT, UNB, UNM, UPRRP, UPS, US, USAS, WTU and XAL for supplying plant material. Three anonymous reviewers kindly provided comments that improved the quality of the article. We are also grateful to Tom Van Devender, Ignacio García Ruiz, Eleazar Carranza, and Miquel García for sending additional plant material. This research was supported by NSERC of Canada Discovery grants to M. Costea (327013-06) and S. Stefanović (326439-06). 


\section{— LITERATURE CITED}

Ainouche, M.L. \& Bayer, R.J. 1997. On the origins of the tetraploid Bromus species (section Bromus, Poaceae): Insights from the internal transcribed spacer sequences of nuclear ribosomal DNA. Genome 10: 730-743.

Álvarez, I. \& Wendel, J.F. 2003. Ribosomal ITS sequences and plant phylogenetic inference. Molec. Phylog. Evol. 29: 417-434.

Austin, D.F. 1982. 165. Convolvulaceae. Pp. 1-98 in: Harling, G. \& Sparre, B. (eds.), Flora of Ecuador, vol. 15. Göteborg, Stockholm: University of Götenborg, Riksmuseum.

Bonpland, A.J.A., von Humboldt, F.W.H.A. \& Kunth, C.S. 1818. Nova genera et species plantarum, Tome troisième. Paris: Librariae Graeco-Latino-Germanicae.

Buckler, E.S., Ippolito, A. \& Holtsford, T.P. 1997. The evolution of ribosomal DNA: Divergent paralogues and phylogenetic implications. Genetics 145: 821-832.

Choisy, J.D. 1841. De Convolvulaceis dissertatio tertia, complectens Cuscutarum hucusque cognitarum methodicam enumerationem et descriptionem, necnon et brevem gallicam de Cuscutis praefationem. Mém. Soc. Phys. Genève 9: 261-288.

Costea, M. 2007 onwards. Digital Atlas of Cuscuta (Convolvulaceae). https://www.wlu.ca/page.php?grp id $=2147 \& p=8968$.

Costea, M., Aiston, F. \& Stefanović, S. 2008. Species delimitation, phylogenetic relationships and two new species in the Cuscuta gracillima complex (Convolvulaceae). Botany 86: 670-681.

Costea, M., Nesom, G.L. \& Stefanović, S. 2006a. Taxonomy of the Cuscuta pentagona complex (Convolvulaceae) in North America. Sida 22: 151-175.

Costea, M., Nesom, G.L. \& Stefanović, S. 2006b. Taxonomy of the Cuscuta indecora (Convolvulaceae) complex in North America. Sida 22: 209-225.

Costea, M., Nesom, G.L. \& Stefanović, S. 2006c. Taxonomy of the Cuscuta salina-californica complex (Convolvulaceae). Sida 22: 176-195.

Costea, M. \& Stefanović, S. 2009a. Cuscuta jepsonii (Convolvulaceae), an invasive weed or an extinct endemic? Amer. J. Bot. 96: 1744-1750.

Costea, M. \& Stefanović, S. 2009b. Molecular phylogeny of Cuscuta californica complex (Convolvulaceae) and a new species from New Mexico and Trans-Pecos. Syst. Bot. 34: 570-579.

Costea, M. \& Tardif, J.F. 2006. Biology of Canadian weeds. Cuscuta campestris Yuncker, C. gronovii Willd. ex Schult., C. umbrosa Beyr. ex Hook., C. epithymum (L.) L. and C. epilinum Weihe. Canad. J. Pl. Sci. 86: 293-316.

Costea, M., Wright, M.A.R. \& Stefanović, S. 2009. Untangling the systematics of salt marsh dodders: Cuscuta pacifica, a new segregate species from Cuscuta salina (Convolvulaceae). Syst. Bot. 34: 787-795.

Coulter, J.M. 1890. Upon a collection of plants made by Mr. G. C. Nealley, in the region of the Rio Grande, in Texas, from Brazos Santiago to El Paso County. Contr. U.S. Natl. Herb. 1: 29-65.

Davis, C.C., Anderson, W.R. \& Wurdack, K.J. 2005. Gene transfer from a parasitic flowering plant to a fern. Proc. Roy. Soc. London, Ser. B, Biol. Sci. 272: 2237-2242.

Davis, C.C. \& Wurdack, K.J. 2004. Host-to-parasite gene transfer in flowering plants: Phylogenetic evidence from Malpighiales. Science 305: 676-678.

DeBry, R.W. \& Olmstead, R.G. 2000. A simulation study of reduced tree-search effort in bootstrap resampling analysis. Syst. Bot. 49: 171-179.

Engelmann, G. 1859. Systematic arrangement of the species of the genus Cuscuta with critical remarks on old species and descriptions of new ones. Trans. Acad. Sci. St. Louis 1: 453-523.

Felsenstein, J. 1981. Evolutionary trees from DNA sequences: A maximum likelihood approach. J. Molec. Evol. 17: 368-376.

Felsenstein, J. 1985. Confidence limits on phylogenies: An approach using the bootstrap. Evolution 39: 783-791.

Funk, H.T., Berg, S., Krupinska, K., Maier, U.G. \& Krause, K. 2007.
Complete DNA sequences of the plastid genomes of two parasitic flowering plant species, Cuscuta reflexa and Cuscuta gronovii. BMC Pl. Biol. 7: 45. Doi: 10 1186/1471-2229-7-45.

García, M.A. \& Martín, M.P. 2007. Phylogeny of Cuscuta subgenus Cuscuta (Convolvulaceae) based on nrDNA ITS and chloroplast trnL intron sequences. Syst. Bot. 32: 899-916.

Goldman, N., Anderson, J.P. \& Rodrigo, A.G. 2000. Likelihoodbased tests of topologies in phylogenetics. Syst. Biol. 49: 652-670.

Holm, L., Doll, J., Holm, E., Pancho, J. \& Herberger, J. 1997. World weeds: Natural histories and distribution. Toronto: Wiley.

Hunziker, A.T. 1949. Las especies de Cuscuta (Convolvulaceae) de Argentina y Uruguay. Trab. Mus. Bot. (Cordoba) 12: 1101-1202.

Kartesz, J.T. 1999. A synonymized checklist and atlas with biological attributes for the vascular flora of the United States, Canada, and Greenland. First edition. In: Kartesz, J.T. \& Meacham, C.A. (eds.), Synthesis of the North American flora. CD-ROM, version 1.0. Chapel Hill: North Carolina Botanical Garden.

Kishino, H. \& Hasegawa, M. 1989. Evaluation of the maximum-likelihood estimate of the evolutionary tree topologies from DNA sequence data, and the branching order in Hominoidea. J. Molec. Evol. 29: 170-179.

Maddison, D.R. \& Maddison, W.P. 2003. MacClade: Analysis of phylogeny and character evolution, version 4.06. Sunderland, Massachusetts: Sinauer.

Maddison, W.P. 1997. Gene trees in species trees. Syst. Biol. 46: 523-536.

McNeal, J.R., Kuehl, J.V., Boore, J.L. \& dePamphilis, C.W. 2007. Complete plastid genome sequences suggest strong selection for retention of photosynthetic genes in the parasitic plant genus $\mathrm{Cus}$ cuta. BMC Pl. Biol. 7: 57. Doi: 10.1186/1471-2229-7-57.

Moore, W.S. 1995. Inferring phylogenies from mtDNA variation: Mitochondrial-gene trees versus nuclear-gene trees. Evolution 49: 718-726.

Mower, J.P., Stefanović, S., Young, G.J. \& Palmer, J.D. 2004. Gene transfer from parasitic to host plants. Nature 432: 165-166.

Nickrent, D.L., Blarer, A., Qiu, Y.L., Vidal-Russell, R. \& Anderson, F.E. 2004. Phylogenetic inference in Rafflesiales: The influence of rate heterogeneity and horizontal gene transfer. BMC Evol. Biol. 4: 40. Doi: 10.1186/1471-2148-4-40.

Parker, C. \& Riches, C.R. 1993. Parasitic weeds of the world: Biology and control. Wallingford: CAB International.

Posada, D. \& Crandall, K.A. 1998. ModelTest: Testing the model of DNA substitution, version 3.7. Bioinformatics 14: 817-818.

Rambaut, A. 2002. Se-Al: Sequence alignment editor, version 2.0a11. Oxford: University of Oxford. http://tree.bio.ed.ac.uk/software/.

Rambaut, A. \& Drummond, A.J. 2004. Tracer, version 1.3. Institute of Evolutionary Biology, Edinburgh. http://tree.bio.ed.ac.uk/software/.

Rannala, B. \& Yang, Z. 1996. Probability distribution of molecular evolutionary trees: A new method of phylogenetic inference. J. Molec. Evol. 43: 304-311.

Rice, D.W. \& Palmer, J.D. 2006. An exceptional horizontal gene transfer in plastids: Gene replacement by a distant bacterial paralog and evidence that haptophyte and cryptophyte plastids are sisters. $B M C$ Biol. 4: 31. Doi: 10.1186/1741-7007-4-31

Rieseberg, L.H. 1995. The role of hybridization in evolution: Old wine in new skins. Amer. J. Bot. 82: 944-953.

Ronquist, F. \& Huelsenbeck, J.P. 2003. MrBayes 3: Bayesian phylogenetic inference under mixed models, version 3 1.2. Bioinformatics 19: $1572-1574$.

Sang, T., Crawford, D.J. \& Stuessy, T.F. 1995. Documentation of reticulate evolution in peonies (Paeonia) using internal transcribed spacer sequences of nuclear ribosomal DNA: Implications for biogeography and concerted evolution. Proc. Natl. Acad. Sci. U.S.A. 92: 6813-6817.

Sang, T. \& Zhong, Y. 2000. Testing hybridization hypotheses based on incongruent gene trees. Syst. Biol. 49: 422-434.

Shimodaira, H. \& Hasegawa, M. 1999. Multiple comparisons of loglikelihoods with applications to phylogenetic inferrence. Molec. Biol. Evol. 16: 1114-1116. 
Stefanović, S. \& Costea, M. 2008. Reticulate evolution in the parasitic genus Cuscuta (Convolvulaceae): Over and over and over again. Botany 86: 791-808.

Stefanović, S., Kuzmina, M. \& Costea, M. 2007. Delimitation of major lineages within Cuscuta subgenus Grammica (dodders; Convolvulaceae) using plastid and nuclear DNA sequences. Amer. $J$. Bot. 94: 568-589.

Swofford, D.L. 2002. PAUP*: Phylogenetic analysis using parsimony (*and other methods), version 4.0b10. Sunderland, Massachusetts: Sinauer.

Tamura, K. \& Nei, M. 1993. Estimation of the number of nucleotide substitutions in the control region of mitochondrial DNA in humans and chimpanzees. Molec. Biol. Evol. 10: 512-526.

USDA-NRCS (Natural Resources Conservation Service). 2010. PLANTS database. http://plants.usda.gov (accessed April 2010).

Vij, S.P., Singh, S. \& Sachdeva, V.P. 1974. Convolvulaceae. Pp. 623 624 in: Löve, Á., IOPB chromosome number reports XLV. Taxon 23: 619-624.
Welsh, M., Stefanović, S. \& Costea, M. 2010. Pollen evolution and its taxonomic significance in Cuscuta (dodders, Convolvulaceae). Pl. Syst. Evol. 285: 83-101.

Wendel, J.A. \& Doyle, J.J. 1998. Phylogenetic incongruence: Window into genome history and molecular evolution. Pp. 265-296 in: Soltis, D.E., Soltis, P.S. \& Doyle, J.J. (eds.), Molecular plant systematics II. Boston: Kluwer.

Yuncker, T.G. 1921. Revision of the North American and West Indian species of Cuscuta. Illinois Biol. Monogr. 6(2-3): 1-141 (reprint 1970).

Yuncker, T.G. 1932. The genus Cuscuta. Mem. Torrey Bot. Club 18: 113-331.

Yuncker, T.G. 1939. The genus Cuscuta in Argentina. Lilloa 4: 447-462.

Yuncker, T.G. 1965. Cuscuta. Pp. 1-51 in: North American Flora, ser. II, part 4. Bronx, New York: New York Botanical Garden.

Zimmer, E.A., Martin, S.L., Beverley, S.M., Kan, Y.W. \& Wilson, A.C. 1980. Rapid duplication and loss of genes coding for the alphachains of hemoglobin. Proc. Natl. Acad. Sci. U.S.A. 77: 2158-2162.

Appendix 1. Taxa, DNA accession numbers, sources of plant material from which DNA was extracted, and GenBank accession numbers for sequences used in this study. DNA extraction numbers are indicated on the phylogenetic trees in the main text following species names. GenBank accession numbers are given in the following order: $\operatorname{trn} L-F$, ITS (if applicable, multiple clones are separated by forward slash). Sequences newly generated for this study are indicated in bold. A dash indicates the sequence was not obtained. Abbreviations of herbaria in which the vouchers are deposited follow Index Herbariorum.

Cuscuta acuta: 1084, Fosberg 44965 (US), EF194330, EF194565/HM748867/HM748868/HM748869; 1188, Ferreyra \& al. 10665 (USM), HM748863, HM748870/ HM748871. C. desmouliniana: 571, Porter 224 (GH), EU288341, EU288359; 1160, Sanders 12674 (UCR), HM748864, HM748872; 1161, Wider 06-368 (WLU), EU288342, EU288360. C. hyalina: 840, Bosch 25022 (BOL), -, EF194561/EU288365; 875, Hardy \& de Winter 1392 (PRE), EF194318, -; 889, Parvati s.n. (RSA), EF194319, EF194562; 994, Mkhanno 45 (ARIZ), EF194320, HM748873. C. legitima (三 C. umbellata var. reflexa): 577, Spellenberg \& Zucker 12966 (NMC), EF194325, EF194566/EU288370; 1015, Van Devender 94-458 (TEX), EF194326, HM748874/HM748875/HM748876; 1027, Austin \& Austin 7585 (ASU), EF194327, HM748877/HM748878/HM748879/HM748880; 1030, Van Devender \& al. 94-458 (ASU), EF194328, HM748881/HM748882/HM748883/HM748884; 1033, Daniel 2445 (ASU), EF194329, HM748885/HM748886/HM748887/HM748888/HM748889. C. leptantha: 608, Wiggins 20889 (MICH), EF194322, EF194569; 719, Wiggins 14668 (GH), EF194323, EF194570; 884, Fritsch \& Fritsch 1337 (RSA), EF194324, EF194571. C. liliputana: 664, Sivinski 5689 (NY), EU288343, EU288363/EU288364; 665, Neese s.n. (NY), EU288344, EU288362; 848, Metcalfe 1290 (NY), EU288345, EU288361. C. membranacea: 1185, Hunziker 4693 (MO), HM748865, HM748890. C. odontolepis: 587, White 2730 (GH), EF194331, EF194563/HM748891/HM748892/HM748893; 730, Hartman 52 (GH), EF194332, EF194564/HM748894/HM748895/HM748896. C. polyanthemos: 826, Robles 123 (XAL), EF194321, EF194572/EU288366; 1162, Van Devender 2006-809 (WLU), HM748866, HM748897. C. tuberculata: 554, de la Luz 8543 (ARIZ), EF194334, EF194568; 737, Wiggins 15153 (GH), EF194335, EU288367; 762, Daniel \& Butterwick 4341 (NY), EF194333, EF194567; 763, Stevens \& Fairhurst 2052 (MICH), EF194336, EU288368; 764, Carter \& Kellogg 3085 (GH), EF194337, HM748898. C. umbellata (var. umbellata): 516, Fletcher 5857 (UNM), EF194315, EF194558/HM748899; 526, Ward \& Spellenberg 81-167 (ASU), EU288346, -; 557, Blankenhorn 216 (ARIZ), EF194317, EF194560/HM748900/HM748901/HM748902; 576, Silversmith s.n. (NMC), EU288347, HM748903/HM748904/ HM748905; 759, Bleakey 4662 (NMC), EF194316, EF194559; 830, Nee \& Taylor 29575 (XAL), -, EU288369; 1189, Carranza 7045 (WLU); 1190, Carranza 7191 (WLU); GB, Medina s.n. (MA), AJ428053, EF192271. Outgroup: C. serruloba Yunck.: 977, Orcutt 4457 (MEXU), EF194313, EF194555. C. vandevenderi Costea \& Stefanović: 1058, Gentry \& al. 19423 (US), EU426964, EU426958.

Appendix 2. Herbarium vouchers used for taxa description and examined for micromorphology. Species accession code: country, region, locality, elevation (m. a.s.1.), date, collector(s), herbarium acronym

Cuscuta acuta, ECUADOR. Galapagos, Hood Island, Gardner Bay, 20 Apr 1932, Howell 8688 (B, CAS); James Island, Sulivan Bay, 13 Jun 1932, Howell 10048 (B, CAS, G, GH, K, MO, NY); Tower Island, 16 Jun 1932, Howell 10140 (CAS, G, GH, NY); 18 Apr 1923, Wheeler \& al. 21 (GH, NY); Culpepper Island, 25-30 Jan 1964, Hendrickson 5 (CAS, GH); Isabella Island, ca. 4 km W of Puerto Villamil, 50 m, 23 Feb 1965, Wiens 3821 (CAS). Prov. Guayas. La Libertad, 26 Feb 1939, Asplund 5136 (G, NY, UPS, US, S). Prov. Manabi. Bahia de Caraquez, 15 Feb 1981, Sparre 19700 (S). PERU. Dept. Piura. Jalara, 1926, Haught 154a (GH, NY, US). C. desmouliniana, MEXICO. Baja California. Near San Bruno, 7 Nov 1946, Wiggins 11394 (DS, RSA); 25.5 mi S of Santa Rosalia, 7 Feb 1960, Porter 224 (CAS, DS, G, MEXU); Bahia de la Concepcion, 18 Oct 1962, Wiggins \& Wiggins 17968 (CAS, DS, MEXU). Sonora. Mpio. Caborca: 35.2 km W of Caborca on road to Desemboque, 30 44'35"N 112 26'32"W, 63 m, 16 Jan 2002, Van Devender \& Reina-G. 2002-23 (WLU). Mpio. Guaymas: San Carlos, 27 57'42"N 111 03'43"W, ca. 35 m, 26 Dec 2000, Reina-G. \& Van Devender 2000-917 (CAS, US, WLU); 5 mi E of Bahia Kino, 19 Oct 1963, Felger 9046 (ARIZ); Guayamas, 22 Feb 1904, Palmer 1209 (type of C. umbellata var. dubia: US). Mpio. Hermosillo: Isla Tiburón, ca. 12 mi, S from Tecomate, 28 57'20"N 112 24.5', ca. 280 m, [no date], Felger 76-T14 \& al. (ARIZ). Mpio. Huatabampo: $1.9 \mathrm{Km} \mathrm{W}$ of Tierra y Libertad, 26 33'00"N 109 12'45"W, 25 m, Friedman \& Zittere 213-95 (ARIZ). Mpio. Soyopa: Arroyo Los Garambullos, 1.5 km east of Tónichi; 28 34'10"N 10933 00"W, 180 m, 15 Sep 1998, Van Devender \& al. 98-1120 (ARIZ, WLU); 4 Sep 1996, Van Devender \& al. 96-360 (ARIZ, NMC, WLU). C. hyalina var. hyalina, INDIA. Delhi, 8 Aug 1954, Mkhanno 45 (ARIZ); Sep 1960, Parvati s.n. (RSA); NAMIBIA. Windhoeck, March 1931, Bosch 25022 (BOLUS). SOUTH AFRICA. Walvisbay Distr, Hardy \& de Winter 1392 (PRE). TANGANYIKA. Musoma Distr.: Mugungu River, Banagi, 1371 m, Greenway 9965 (PRE). UGANDA. Karamoja District: near Amudat, 1 Jun 1939, Thomas 2989 (K). ZIMBABWE. Chimanimani, Birchenough Bridge, 700 m, 17 Dec 1952, Chase 4741 (K). C. lacerata [the type]. C. legitima (三 C. umbellata var. reflexa), U.S.A. Arizona. Cochise Co.: San Pedro Riparian National Conservation Area, 31 47.667'N, 110 12.519', 1218 m, 19 Oct 2003, Makings 1673 (ASU, CAS, NY). Maricopa Co.: ca. 80 km W of Phoenix, 365 m, 18 Aug 1999, Spellenberg \& Zucker 12966 (NMC). Pima Co.: Cabeza Prieta National Wildlife Refuge, 32 07'N 113 05’W, 365 m, 15 Sep 1992 , Felger \& Gierlach 92-740 (ARIZ, CAS); Tucson, Highland Avenue, 750 m, 20 Aug 1953, Parker 8309 (CAS, MO). Yuma Co.: 0.25 mi intersection of Mohawk Valley Bld. and Avenue 36E, $3243.916^{\prime} \mathrm{N} 114$ 0.259'W, 75 m, 7 Jun 2003, Northam s.n. (MO). Kansas. Hamilton Co.: 1 mi S of Coolidge, 23 Sep 1972, McGregor 24751 (NY). New Mexico. Dona Ana Co.: College Ranch ca. $15 \mathrm{mi}$ N of Las Cruces, 5 Sep 1970, Spellenberg \& Spellenberg 2379 (NMC). Texas. Brewster Co.: Big Bend National Forest, 22 Jul 1957, Correll \& Johnston 18334 (UC); Starr Co.: Fort Ringgold, 45 m, 13 Jul 1941, Runyon 2727 (UC). MEXICO. Baja California. 9 mi E of La Paz, 25 Nov 1959, Wiggins 15613 (ARIZ, CAS); ca. 23.5 mi N from Pozo Grande, 100 m, 28 Oct 1959, Thomas 8373 (DS, ARIZ, MEXU); Loreto, 23 Oct 1930, Jones 27348 (CAS, MO); La Paz, 29 Oct 1969, Thomas 8414 (CAS, MEXU). Chihuahua. 13 Km E of Guzman, 31 10’N 107 23’W, 1130 m, 22 Aug 1972 , Chiang \& al. 8798 
Appendix 2. Continued.

(CAS). Coahuila. Mpio. Cuatro Ciénegas and Ocampo: Loma Prieta, 27 09'50" N 102 16'30"W, 1000 m, 2 Oct 1976, Wendt \& al. 1862 (MEXU). Sonora. Mpio. Agua Prieta: S edge of Agua Prieta, 3118 21"N 109 34'55"W, 1204 m, 13 Sep 2006, Van Devender \& Reina-G. 2006-757 (HCIB, MO, TEX, WLU). Mpio. Álamos: Capitahuasa, 26 45'35"N 108 55'W, 160 m, 25 Sep 1993, Van Devender \& al. 93-1123 (ARIZ, UC, UCR). Mpio. Cajeme: Ciudad Obregon, 29 Sep 1933, Gentry 272 (ARIZ, MICH); Cerro La Antena, 27 27'45"N 109 46'20"W, 200 m, 19 Sep 1994, Van Devender \& Yetman 94-603, (ARIZ, ASU, MEXU, UC, USON); NW side of Río Yaqui, ca. 9 km N of Ciudad Obregón; 27 35'45”N 109 56’W, 40 m, 10 Sep 1994, Van Devender \& al. 94-458 (ARIZ, ASU, MEXU, UC, UCR). Mpio. Hermosillo: $20 \mathrm{mi} \mathrm{S}$ of Hermosillo, 28 Oct 1926, Jones s.n. (MO); $27 \mathrm{mi} \mathrm{W}$ of Hermosillo, on road to Kino Bay, 28 Aug 1941, Wiggins \& Rollins 133 (ARIZ, DS, MO). Mpio. Navojoa: San José de Masiaca; 26 45’N 109 14'30"W, 70 m, 22 Sep 1994, Van Devender \& Yetman 94-710, 94-711 (ARIZ, MEXU, UC). Mpio. Puerto Peñasco: MacDougal Crater, 8 Sep 1964, Felger 10488 \& Lincoln (ARIZ); 0.5 km E of MacDougal Crater, 8 Sep 1964, Felger 10432A, 10435,10436 (ARIZ); W Pinacate, 6 Nov 1982, Equihua s.n. (ARIZ); Sykes Crater, NW of Pinacate Region, 155 m, 8 Dec 1970, Burke \& al. 20035 (ARIZ); ca. 1 Km SW Papago Tanks, 28 Sep 1964, Felger \& Lincoln 10608 (ARIZ); Rancho Grijalva (Rancho Guadalupe Victoria), 32 00'35"N 113 34'25"W, 225 m, 9 Nov 1982, Ezcurra s.n. (ARIZ). Mpio. Soyopa: Tónichi, 28 35'55"N 109 33'50"W, 200 m, 17 Aug 2006, Van Devender \& Reina-G. 2006-627 (ARIZ, NMC, WLU); 3.5 km S of Tónichi, ca. 28 34'03"N 109 33'25"W, 220 m, 17 Aug 2006, Van Devender \& Reina-G. 2006-638 (WLU); Arroyo los Conejos, 28 35'39"N 109 35'33"W, 225 m, 16 Aug 2006, Reina-G. \& Van Devender 2006-586 (MEXU, WLU); Reina-G. \& Van Devender 2006-606, 2006-612 (WLU). Tamaulipas. vicinity of Victoria, ca. 320 m, May 1-Jun 13 1907, Palmer 441 (K, MO, NY). C. leptantha, U.S.A. Texas. Karnes Co.: $0.3 \mathrm{mi} \mathrm{NW}$ of Falls City, 5 Oct 1952, Johnson 1032 (BRIT, NY). MEXICO. Baja California. 1/2 mi N of fork of Rd to Rancho San Pedro, ca. 24 51'N 11104 W, 225 m, 15 Nov 1959, Wiggins 15478 (DS, MEXU); ca. 3 mi S of Santa Rosalia, 24 May 1959, Thomas 7971 (MEXU); 5.8 mi from La Paz, 30 Dec 1956, Porter 123 (G, MEXU); Cape Region, near 24 11'N 110 12'W, 4 Jan 1959, Moran 6882 (CAS, DS, K, RSA, SD). SONORA. Mpio. Hermosillo: ca. $1.5 \mathrm{mi}$ E of Santa Rosa, $15 \mathrm{Feb}$ 1965, Felger \& al. 12575 (ARIZ); 4 mi by road NW of Rancho Noche Buena, 14 May 1966, Felger \& al. 14035 (ARIZ); ca. $1 \mathrm{mi}$ E of $19 \mathrm{mi}$ by road S of Desemboque, ca. $2920^{\prime} \mathrm{N} 112$ 14' W, 18 Feb 1968, Felger \& al. s.n. (ARIZ); $3.7 \mathrm{mi}$ S of Punta Chueca, 13 Apr 1980, Bowers \& McLaughlin 1966 (ARIZ). Playa Esthela, 2852 28" N 112 01'20", 50 m, 31 Dec 2000, Van Devender \& Reina-G. 2000-933 (WLU). Mpio. Pitiquito: $19.8 \mathrm{mi}$ S of Desemboque Río San Ignacio, 14 May 1966, Felger \& Bezy 14080 (ARIZ). C. liliputana, see Stefanović \& Costea, 2008. C. membranacea, ARGENTINA. Provincia de la Rioja, Depto. de Capital, La Ramadita, 25 Km of Rioja, 17 Feb 1944, Hunziker 4823 (S, US); 17 Feb 1944, Hunziker 4833 (S, US); 9 Mar 1944, Hunziker 4695 (S). Provincia La Salta, Depto. de la Pima, 2 Feb 1941, Hunziker 1149 (NY). C. odontolepis, MEXICO. Chihuahua. Nabogame, 12 Km NW of Yepachic, 28 30'N 108 30’W, 1800 m, 23 Oct 1986, Laferriere 318 (MEXU). Sonora, Mpio. Arispe: 5 Km of NW Bacanuchi, 30 39'22"N 110 15'52"W, 1880 m, 22 Nov 1997, Flores 5143 (IEB, USON). Mpio. Arivechi: Arroyo Bámori, 5 km S Bámori, 28 49'15"N 109 10 24"W, 536 m, 15 Sep 2006, Van Devender \& Reina-G. 2006-869 (ARIZ, USON, WLU). Mpio. Cucurpe: Palm Canyon, 30 29'N 111 46' W, 1300 m, 2 Oct 1976, Van Devender \& al. s.n. (ARIZ). Mpio Fronteras: 1387 m, 25 Sep 1890, Hartman 52 (K, US); S edge of Esqueda on SON 17, 30 42'41"N 109 35'15"W, 1215 m, 13 Aug 2006, Van Devender \& Reina-G. 2006-467 (ARIZ, MEXU, WLU). C. polyanthemos, MEXICO. Sinaloa. $22.6 \mathrm{mi} \mathrm{S}$ of Culiacan, $140 \mathrm{~m}, 17$ March 1955, Wiggins 13153 (CAS, SD). Sonora. Mpio. Quiriego: 31 mi NW of Quiriego on Rd to Cajeme, 6 Mar 1933, Wiggins 6457 (CAS). Mpio. Moctezuma: 18.9 km SSE of junction with Moctezuma-Huásabas Hwy on road to Tepache, 29 39'N 44"N 109 37'13"W, 635 m, 14 Sep 2006, Van Devender \& Reina-G. 2006-809 (WLU). C. tuberculata, U.S.A. Arizona. Maricopa Co.: South Mts., T1S R3E NW1/2 Sec. 20, 580 m, 15 Sep 1985, Daniel \& Butterwick 4341 (CAS). Pinal Co.: Picacho Pass, 10 Sep 1971, Beauchamp 3112 (SD). Yuma Co.: Mohawk, 17 Sep 1929, Jones 24949 (CAS, UC). Yavapai Co.: 3 mi S of Yarnell, 26 Aug 1989, Austin \& Austin 7587 (RSA, ASU). MEXICO. Sonora. Mpio. Álamos: Mocúzari (Adolfo Ruiz Cortinez) Dam on the Río Mayo, WNW of Álamos, 27 13'10"N 109 06'30"W, 120 m, 16 Oct 1992, Van Devender \& Van Devender 92-1386 (ARIZ, ASU, CAS, UCR). Mpio. Hermosillo: 8 mi W of Hermosillo, 27 Aug 1941, Wiggins \& Rollins 98 (ARIZ, DS, MO); ca. 25 km W of Hermosillo on Rd. to Bahía de Kino, 29 01'29"N 111 08'33"W, 10 Aug 2001, Reina-G. \& Van Devender 2001-624 (ARIZ, MEXU, USON, WLU). Mpio. La Colorada: 36 Km, SE of Hermosillo on MEX 16, 28 49'54"N 110 39'25"W, 317 m, 15 Aug 2006, Van Devender \& Reina-G. 2006-552 (HCIB, USON, WLU); 4.7 Km E of Tecoripa on MEX 16, 28 37'04"N 109 54'25"W, 410 m, 16 Aug 2006, Reina-G. \& Van Devender 2006-559 (ARIZ, CAS, WLU). Mpio. General Plutarco Elias Calles: 2.7 mi W of Sonoyta on Mex Hwy 2, 14 Sep 1986, Felger 86-315 (ARIZ). Mpio. Moctezuma: 141 km SSE of Moctezuma on road to Tepache, 29 40'53"N $1093800^{\prime \prime} \mathrm{W}, 607 \mathrm{~m}, 14$ Aug 2006 , Reina-G. \& Van Devender 2006-544 (MO, TEX, WLU). Mpio. Opodepe: Querobabi, 30 03'14"N 111 01'39"W, 680 m, 20 Aug 2001, Reina-G. \& Van Devender 2001-730 (ASU, HCIB, NMC, WLU). Mpio. Soyopa: Arroyo Los Garambullos, $05 \mathrm{~km}$ SE of Río Yaqui bridge on MEX 16, $3.3 \mathrm{~km} \mathrm{S,} 1.5 \mathrm{~km}$ E of Tónichi, 2834 '10"N 10933 00"W, 180 m, 15 Sep 1998, Van Devender \& al. 98-1111 (ARIZ, WLU). Mpio. Puerto Peñasco: Pinacate Region, Sykes Crater, 400 m, 8 Dec 1970, Burke \& al. 19998 (ARIZ). C. umbellata var. umbellata, U.S.A. Arizona. Apache Co.: Hubbell Treading Post National Historic Site, UTM 125: 630137E, 3951920N, 1920 m, 19 Sep 2002, Roth s.n. (NMC, BRIT). Colorado. Fremont Co.: 28 Jul 1813, Brandegee 407 (UC). Otero Co.: Fowler, R-59w T-22s, 1320 m, 10 Sep 1980 , McIntyre \& Anderson 75 (MO). New Mexico. Dona Ana Co.: S edge of Las Cruces, 7 Jun 1981, Ward \& Spellenberg 81-167 (NMC, NY, MO, TEX). McKinley Co.: ca. 33 mi N of Milan, 3538 950"N 107 52'141"W, 2145 m, 20 Sep 2002, Bleakley 4662 (NMC). San Miguel Co.: head of Cuevas Canyon, 20 mi ESE of Las Vegas, 1850-1920 m, Hill \& Levandoski 11952 (MO). Santa Fe Co.: ca. 10 mi NW of Santa Fe, 35 45'59.8"N 106 02'13.4"W, 11 Oct 2002, Cox s.n. (NMC, BRIT). Torrance Co.: ca.10 mi W of Mountainair, T3N R5E Sec NW1/4, 1950 m, 14 Sep 2002, Sivinski \& al. 5669 (NMC). Texas. Culberson Co.: 36 mi N of Van Horn, 27 Jul 1952, Webster 4527 (BRIT); 13 Oct 1985, Spellenberg s.n. (NMC, UC). El Paso Co.: 1 mi N of El Paso, 23 Sep 1944, Barkley 14535 (BRIT, K); 11 Sep 1988, Worthington 17336 (CHSC, UNM); just W of Ft. Bliss, 1100 m, 12 Oct 1950, Dunn 7208 (NMC). MEXICO. Coahuila. Caňon de Agua, 3.5 mi NNW of Cuatro Ciénegas, 14 Aug 1967, Minckley \& Pinkava 3864 (ASU). Chihuahua. Near Chihuahua, 31 Aug 1887, Pringle 783 (G, MO, MEXU); Camino de Aldama to Río Conchos, 25 Aug 1966, Robert s.n. (MEXU). Distrito Federal. Between Santa María Astahuacán and Santa Cruz Meyehualco, 2250 m, 1 Jun 1966, Rzedowski 22418 (IEB, MEXU). Durango. Mpio. De Gómez Palacio: Cerro San Ignacio, 17 Jul 1984, Pacheco 9 (MEXU); 26 Km WSW of Torreón, 25 27’N 103 42’W, 1225 m, Iltis \& Lasseigne 96 (MEXU). Guerrero. Mpio. Coahuayutla de Guerrero: 5.46 km N of La Corva, 18 32'8"N 101 50'28", 20 Oct 1999, Soto 17626 (MEXU). Guanajuato. Mpio. de Yuridia: Yuridia Lake, 1850 m, 29 Aug 1970, Rzedowski 27592 (IEB); 3 km al NW of Cuitzeo on Hwy to Salamanca, 1850 m, 18 Aug 1986, Rzedowski 40388 (IEB). Estado de Mexico. Mpio. de Tultepec: 2 Km of Salinas, 2250 m, 23 Aug 1963, Rzedowski 17099 (IEB, MEXU). Jalisco. Ca. 4.5 mi from Zacoalco on Rd to Acatlán, 16 Sep 1969, Dieterle 3471 (MICH, MEXU). Michoacan. Mpio. de Santa Clara: La Lagunita, San Gregorio, 2700 m, 4 Dec 1986, Barriga 3422 (IEB). Mpio. Huaniqueo: 1.8 Km of SW Tendeparacua, 2050 m, 7 Oct 1992, Silva-Sáenz 351 (EBUM, IEB). Mpio. de Patzcuarro: Cerro del Frijol, 2550 m, 10 Dec 1985 , Escobedo 760 (IEB). Nuevo Leon. El Manantial, 26 23'N 100 55’W, 560 m, 22 Aug 1984, Carranza \& al. 2640 (MEXU). Oaxaca. Mpio. de Santa Maria Tecomavaca: 3 mi S of Tecomavaca, 550 m, 12-13 Aug 1976, Webster 20792 (MEXU, MO, UC). Mpio. San Juan Bautista Cuicatlán: 10.2 Km al NE of Chilar, $1747^{\prime 2} 21$ N 96 59'31", 665 m, 1 Oct 2002, Soto 24009 (MEXU). Queretaro. Mpio. de Peňamiller: 1 km SW of Higuerillas, 1400 m, 12 Aug 1989, Zamudio 3698 (IEB). San Luis Potosi. Mpio. de Tierra Nueva: 5 Km al NNW of Tierra Nueva, 1750 m, 9 Jun 1959, Rzedowski 10786 (MEXU). Sonora. Mpio. General Plutarco Elias Calles: Quitovac, 2 Sep 1980, Nabhan \& Rea 167 (ARIZ); 0.5 km E of Río Sonoyta, 4 Oct 1985, Felger \& Van Houten 85-940 (ARIZ). Puebla. Mpio Tehuacan: near Tehuacan, 1675 m, 24 Dec 1896, Pringle 6297 (G, MEXU, MO, US). Mpio. San José Miahuatlán: 18 13’N 97 13', 950 m, 4 Nov 1993, Salinas \& al. 7610 (MEXU). Tamaulipas. Mpio. San Carlos: 24 16.8'N 98 59.4W, 360 m, 27 Nov 1998, Martinez 5030 (MEXU). Veracruz. Close to the border with Puebla on Rd to Xalapa, 12 Jul 1969, Ramos 295 (MEXU). PANAMA, Distr. de Parita: Sarigua, $1 \mathrm{Km}$ of Linon Harbour, 9 Oct 1984, Caballero \& Sandoval 57 (MO). ANTIGUA AND BARBUDA. Antigua Island, 1857, Wullschlagel 352 (MO). PUERTO RICO. Guanica, 11-12 Mar 1913, Britton \& Shafer 1866 (GH, MO, NY); Mona Island, ca. $1 \mathrm{Km}$ N of the lighthouse, 25 Jan 1992, Proctor \& al. 47591 (UPRRP). CUBA. 1860-1864, Wright 3107 (K, GH, MO, NY, S). Prov. Oriente: Santiago, 22 Jun 1914, Ekman 1419 (S). HAITI, Massif de la Selle, 21 Jul 1926, Ekman 6714 (K, S). JAMAICA. Parish Kingston: Palisades, 15 Feb 1966, Adams 12882 (MO); Georges Lane, back of Institute of Jamaica, 24 Jul 1957, Proctor 16497 (GH). TURKS \& CAICOS. Grad Turk: North Wells, 12 Jun 1974, Proctor \& Gillis 34044 (B, GH); 28 Nov 1977 , Correll 49198 (GH, MO). South Caicos, vicinity of Cockburn Harbour, 17 Jun 1954, Proctor 8819 (GH). VIRGIN ISLANDS. Anegada, 2 Aug 1970, D'Arcy 4904 (MO). BRITISH GUIANA. Georgetown, 29 Oct 1919, Hitchcock 16564 (GH, NY, S). SURINAME. Nickerie, 21 Feb 1951, Geyskes 30 (GH); just S. of Braamspunt, 18 Nov 1960 , Boxtel 2109 (NY). VENEZUELA. La Guaira, 18 Mar 1940, Tamayo 1247 (NY, US). CAPE VERDE. Medina s.n. (MA). C. umbellata var. desertorum, BRAZIL. Prov. Piauhy, Martius s.n. (the holotype, MO); Prov. Ceara, Gardner 2425 (K). 